\title{
Social Risk Assessment and Management for Major Construction Projects in China Based on Fuzzy Integrated Analysis
}

\author{
Junxia Miao $\mathbb{D}^{1,2}$ Dechun Huang, ${ }^{1,3}$ and Zhengqi He $\mathbb{C}^{1,3}$ \\ ${ }^{1}$ Department of Finance, Business School of Hohai University, Nanjing 211100, China \\ ${ }^{2}$ School of Applied Mathematics, Nanjing University of Finance and Economics, Nanjing 210046, China \\ ${ }^{3}$ Hohai Industrial Economics Institute, Nanjing 211100, China \\ Correspondence should be addressed to Zhengqi He; hzq1309@hhu.edu.cn
}

Received 19 March 2019; Revised 15 August 2019; Accepted 29 August 2019; Published 20 November 2019

Academic Editor: Roberto Natella

Copyright ( $\odot 2019$ Junxia Miao et al. This is an open access article distributed under the Creative Commons Attribution License, which permits unrestricted use, distribution, and reproduction in any medium, provided the original work is properly cited.

With the vigorous development of major engineering projects in China, the social risks associated with major construction projects not only challenge the success of projects but also threaten social harmony and stability. Therefore, it is of great practical significance to assess and manage social risks. This paper aims to identify and evaluate the social risk factors by conducting a survey and assess the overall risk level of major construction projects (MCPs) with fuzzy integrated approach. First, 35 social risk factors and related stakeholders were identified based on literature analysis and case study. Then, 18 critical social risk factors (CSRFs) were selected and classified into six groups (CSRGs) based on a questionnaire survey. Next, using fuzzy integrated method, the probability of occurrence (PO), magnitude of impact (MI), the integrated risk level (IRL) of each CSRF and CSRG, and the overall risk of MCPs were calculated. As a result, "unfair compensation for housing demolition and land requisition" was the most critical social risk factor, and "policy/legal risk" was the most critical social risk group. The overall risk of MCPs was between moderate and high. At last, a social risk synthetic management framework was established, which can provide reference for policymakers and project decision makers to effectively manage the social risks.

\section{Introduction}

MCPs (major construction projects) are generally public welfare projects invested by the government, and they have significant impacts on the economy, society, environment, security, and safety of wide regions or even the entire country [1]. In recent decades, major construction projects such as South-to-North Water Transfer Project, BeijingShanghai High-Speed Railway, Hangzhou Bay Bridge, and Hong Kong-Zhuhai-Macao Bridge have been carried out in China.

Nevertheless, when compared with common projects, MCPs are usually large scale, have long time span, and have wide space scale, involving high levels of complexity and uncertainty. In the life cycle of a project construction, it often involves immigration, land acquisition and demolition, environmental pollution, which can affect and destroy the traditional lifestyle and living environment, and interests of local farmers. The conflicts among local governments, managing sectors, and the affected people constantly occur [2]. Without effective management and decision-making, the conflicts among stakeholders have become more predominant and subsequently will result in grave consequences, such as increasing disposal costs, economic loss, cancelation, or postponement of the projects. Even worse, community petitions and incidents, originated in serious conflicts, will affect social stability seriously. A case of this negative influence is the " $10 \cdot 14$ Incident": on October $14^{\text {th }}, 2014$, a massive violence exploded between construction personnel and local residents in Jinning County, Yunnan Province, resulting in eight deaths and 18 injured [2]. The conflict was caused by the construction of "PanAsian Industrial Products Trade and Logistics Center Project" mainly because villagers believed that their interests were seriously damaged and the original compensation plan could not meet their needs. Another mass emergency 
happened in Qidong City, Jiangsu Province. On July $28^{\text {th }}$, 2012, the local people occupied the municipal government buildings which caused a certain negative impact on the society. The incident was triggered by the approval of the Nantong Municipal Government of Jiangsu Province for the paper-making and sea-discharging project of the Prince of Japan. These conflicts showed that the megaprojects have become the intersection of social contradictions in the new period of our country. Therefore, it is a must to carefully analyze social risks, including the identification, estimation, and management of risk factors and related stakeholders, based on which social risks can be mitigated and controlled in a proper manner [3].

Social risks are product of social development and modern civilization. In the Chinese context, social risks come from the conflicts of interest among different stakeholders and are typically associated with mass incidents, violent resistance, and social conflicts [4]. Kasperson et al. [5] indicated that risks could be socially amplified when risk events interact with psychology, society, and culture. Improper handling of social problems will endanger social stability. The central government of China has also attached great importance to the harmonious and stable development of society. Social risks cannot be fully eliminated, rather, it can be effectively managed to mitigate the negative impacts [6].

To assess the social risks for MCPs and mitigate negative impacts correspondingly, social risk assessment framework needs to be established. Therefore, we investigated large hydraulic engineering projects in China through a questionnaire survey, identified critical social risk factors, established a social risk fuzzy assessment framework, and assessed the overall social risk level. The results can aid decision makers in decreasing a project's risk exposure and promote the sustainable development of the project and the society.

This paper is organized as follows. Section 2 provides a literature review on social risks and stakeholder management for major construction projects. Research framework is presented in Section 3, followed by the identification of the social risks and stakeholders of MCPs based on the analysis of case studies and questionnaire surveys in Section 4. In Section 5, after calculating the PO, MI, and IRL of each CSRF and CSRG, a social risk evaluation framework is presented with fuzzy approach. Finally, a social risk management framework is established to effectively manage the projects.

\section{Literature Review}

Project risk is commonly defined as an uncertain event or condition that, if it occurs, has a positive or negative effect on one or more project objectives [7]. The prevailing definition of risk in the social field is defined as uncertain and serious events or consequences due to a certain valuable activity $[2,8]$. Risk is inherent in every ongoing project. The identification and estimation of risk is the key element in the risk management process [9].

To comprehensively and systematically assess the risks of construction projects, many approaches have been applied, such as AHP [1, 10], fault tree analysis [11], and expected utility [12]. Recently, many risk assessment approaches have been used based on linguistic terms (such as low probability and high risk) instead of numerical values. These terms cannot be defined with an exact single value, but fuzzy set theory provides the means by which these terms may be formally defined in mathematical logic [13]. Samantra et al. [5] proposed a risk assessment model for metropolitan construction projects based on fuzzy theory. The authors identified 20 risk factors related to design, management, safety, natural hazards, social, and economy and ranked the critical risk factors. Zhang et al. [11] presented a probabilistic decision approach for safety risk analysis for metro construction and proposed an expert confidence index for the fuzzy probability estimation of basic events. Using fuzzy AHP, Nieto-Morote et al. [13] presented a risk assessment of a rehabilitation project of a building. Bavafa et al. [14] also identified and assessed the causal relationships of safety program factors in the construction projects in Kuala Lumpur using Fuzzy Delphi Method and DEMATEL. Taylan et al. [15] attempted to select the project through the combination of fuzzy AHP and fuzzy TOPSIS theory. Kou and Lu [16] employed fuzzy AHP to evaluate the risk for a metropolitan construction project. They also used the consistent fuzzy preference relations (CFPR) method for relative impact assessment. Xu et al. [17] proposed a fuzzy synthetic evaluation model for assessing the overall risk of highway construction PPP projects in China. Using fuzzy DEMATEL-ANP, Mavi and Craig [18] identified critical success factors of sustainable project management in construction.

The aforementioned research studies mainly involved cost overruns, quality problems, overtime, etc. However, with the progress of society, people have higher requirements for projects, not only focusing on traditional risks (e.g., time planning and cost control), but also on the social performance of projects (e.g., environment, sustainable development, and harmony with the people). Recently, social risk has become a hot topic. From the qualitative perspective, Zhang [19] identified the key social risk factors associated with international contractors from a questionnaire survey and a case study; Liu et al. and Shi et al. [2, 20] explored how to identify and manage social risks and developed response plans to prevent, mitigate, and cope with the potential consequences of social risk events that may occur before or during the implementation process.

Research studies on social risk are mainly based on Baker's [21] research on "Risk." Social risk can be understood as the challenges faced between stakeholders and companies on the social consequences of their business practices [3]. Social risk has diverse meanings in different disciplines and society backgrounds. In the Chinese background, social risk owns its specified implication and particularly refers to those group events (such as public confrontation, open protest, and violent conflict) due to the conflicts of interest among different stakeholders [2]. Based on indigenous analysis of construction projects in China, Xiang and Luo [22] indicated that social stability risk can be prevented and resolved by reducing risk source and preventing risk pathway. Based on the vulnerability of the social 
system, Huang et al. [23] proposed a social risk assessment model of a large hydraulic construction that consists of social risk exposure and public risk perception.

Social risk management is characterized by a systematic process of identifying and classifying, analyzing and assessing, responding, and controlling risks [24, 25]. Holzmann and Jørgensen [26] constructed a social risk management framework. This framework aimed to help individuals, families, and communities manage social risks and provided support to the critically poor. They proposed that social risk management included prevention, mitigation, and coping strategies. Therefore, from this point of view, social risk management is closely related to stakeholder management.

Using a social network analysis, Yuan et al. [3] established an improved analysis model of social risk for construction projects in high-density urban areas, considering the interrelationships between stakeholders and risks. For large hydraulic engineering projects, $\mathrm{He}$ et al. [27] investigated the relevant risk factors and considered the relationships among stakeholders and their linkages of risks based on social network analysis. By systematic literature review on the current construction literature, Xia et al. [25] put forward that integrated management of construction risk and stakeholder is feasible and can promote the effectiveness of management.

In summary, the study of social risk is still in its infancy, and the existing work on this research area had some deficiencies. First, the existing assessment model did not evaluate the overall social risk for MCPs. Second, the previous social risk model did not consider fuzziness within the projects. Since risk assessments in MCPs are often multilayered and fuzzy in nature, which require evaluators' subjective judgment, it is appropriate to adopt fuzzy theory to establish a fuzzy risk assessment model for MCPs [17]. Taking into account the features of MCPs, this paper established a social risk fuzzy assessment model for assessing the risk level of CSRGs and the overall risk level of MCPs in China.

\section{Research Framework}

Risk analysis is the process of identification, analysis, and response, either the acceptance or mitigation of uncertainty in decision-making [28]. In this paper, large hydraulic engineering projects are selected as illustration cases for developing a social risk evaluation model.

Research framework is presented in Figure 1. The research frame includes the following: (i) Identify social risk factors through cases analysis and a wide literature survey, and then select the critical risk factors through a two-round questionnaire survey and expert judgments. (ii) Assess social risks based on fuzzy integrated analysis technique. (iii) Establish a social risk management structure combined risk management with stakeholder management.

\section{Identification of Social Risk Factors and Stakeholders}

In this section, first, we identified the underlying social risk factors and stakeholders through case studies and literature reviews. Second, by means of a questionnaire survey and face-to-face interviews, after investigating large hydraulic engineering projects in China, CSRFs were selected and classified.

4.1. Underlying Social Risk Factors and Stakeholders with Case Study. The case study analysis can provide effective means to identify and understand factors that contribute to the failure of the studied projects. In this section, we selected 15 conflict incidents from years 2005 to 2018 by web search according to the following criteria [3]:

(1) The case must be a major construction project

(2) The case must be related to social risk events (collective conflicts)

(3) The case should not be out of date (not a long time away from the day of case collection)

The social risk factors and stakeholders (see Table 1) are identified by a study group discussion.

4.2. Social Risk Factors and Stakeholders with Literature Analysis. In this section, through wide-ranging literature resources, following the discussion of the project team, the social risk factors and related stakeholders were summarized. A primary list of 33 risk factors were obtained and identified as shown in Table 2.

4.3. Determining CSRFs. In this section, to identify CSRFs and effectively determine the evaluation criteria, we conducted a two-round questionnaire survey for data collection, and this method has been used in project risk analysis $[21,29,31]$. The detailed steps are summarized as follows:

\section{Step 1. Experts' selection.}

In order to obtain reliable data and to limit subjectivity, we selected experts who satisfied at least one of the following criteria:

(1) Experts who have extensive experience within construction projects of China

(2) Experts who have been involved in at least one project, with in-depth knowledge of risk management in construction project in China or have gained abundant knowledge about risk management through research

Step 2. Questionnaire dissemination and data analysis.

A two-round questionnaire survey was conducted. In the first round of the questionnaire survey, we designed a structured questionnaire consisting of two parts: (1) thirtythree potential social risk factors, and each risk factor has been described by (i) probability of occurrence (PO) and (ii) magnitude of impact (MI) based on a 7-point Likert scale $(1=$ absolutely low $(\mathrm{AL}), 2=$ very low $(\mathrm{VL}), 3=$ low $(\mathrm{L})$, $4=$ moderate $(\mathrm{M}), 5=$ high $(\mathrm{H}), 6=$ very high $(\mathrm{VH})$, and 7 = absolutely high (AH) for PO and $\mathrm{MI}$ ); and (2) additional 


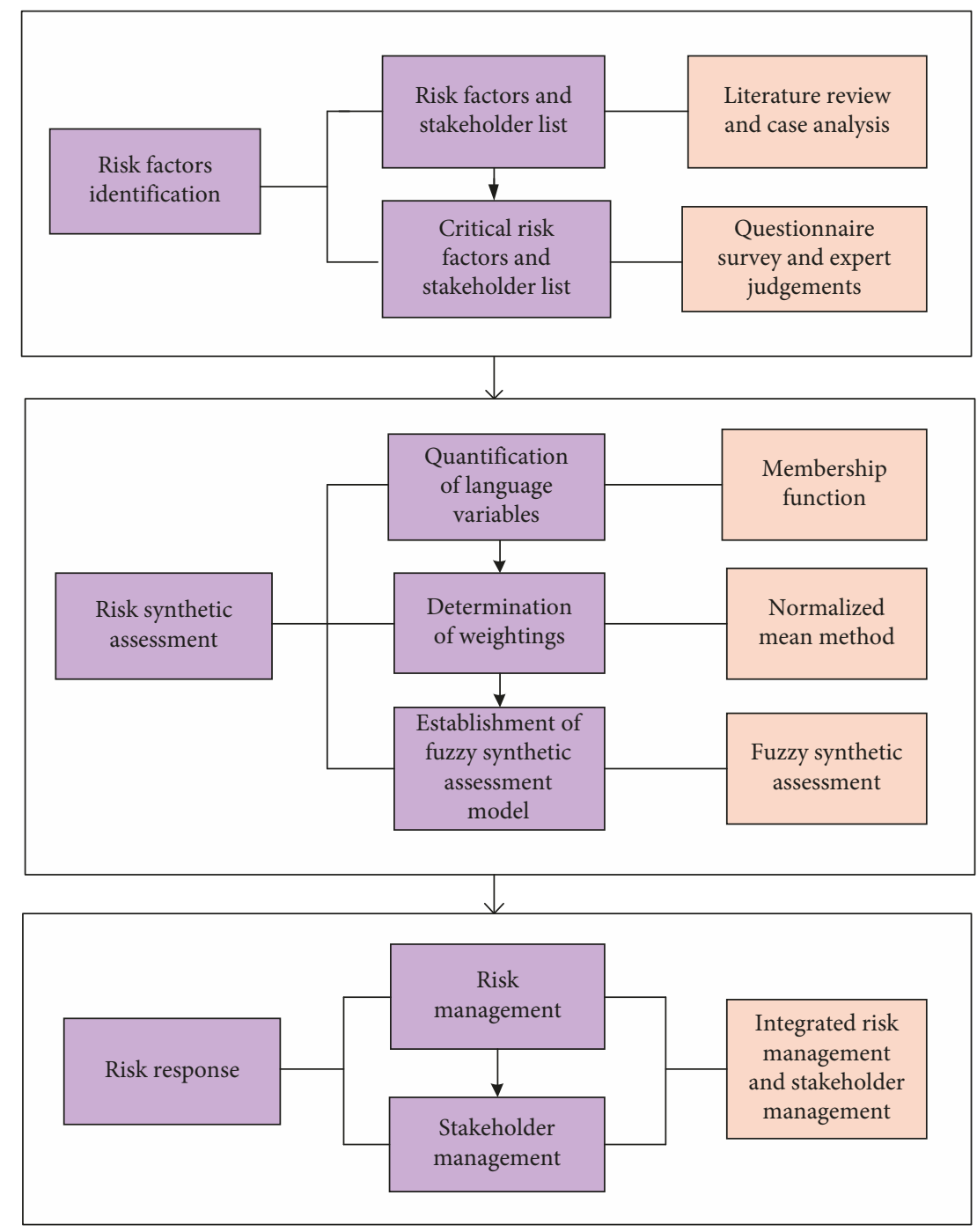

FigURE 1: Risk assessment and management framework.

risk factors which were not included in the questionnaire survey (see Appendix).

Through the online questionnaire and personal interviews, we distributed questionnaires and asked experts to answer the questions according to their own knowledge and experience. As a result, the new added risk factors were "media dissemination" and "decision-maker moral".

In the second round, experts were invited to check on updated risk factors and reconsider their estimation about OP and MI of each risk factor. A total of 28 questionnaires were sent out, and feedback from 16 experts (see Table 3) was received, yielding a response rate of $57 \%$. It was supposed to be satisfactory for the purposes of this research.

In addition, face-to-face interviews were also conducted with 26 stakeholders in a certain village, where more than one hundred inhabitants live. These semistructured interviews posed some questions regarding social risk factors (see Appendix B). The results will help us examine and identify the social risk factors.

At last, in order to ensure the validity of questionnaire data, questionnaires should be subjected to statistical analysis to confirm their reliability and validity [19, 30]. Cronbach's alpha coefficient is the most commonly used at present. If the Cronbach's alpha coefficient is higher than 0.7 , the reliability of the questionnaire data would be proven $[14,30]$. Based on SPSS software, the Cronbach's alpha values of probability and severity of the data used in this study were calculated to be 0.962 and 0.967 , respectively, indicating that the risk factors showed high internal consistency and that the questionnaire was reliable.

\section{Step 3. Ranking social risk factors.}

According to the information from experts, we calculated the average score of $\mathrm{PO}$ and $\mathrm{MI}$ of each risk factor, and the integrated risk level (IRL) $(\mathrm{IRL}=\sqrt{\mathrm{PO} \times \mathrm{MI}})$ and ranked them based on IRL values in descending order, and then, normalizing corresponding IRL with equation (1). The results are shown in Table 2.

$$
y_{n}=\frac{y_{i}-y_{\min }}{y_{\max }-y_{\min }}
$$

where $y_{i}$ is the value of IRL (see Table 2) which measures the rating of risk impact of a particular risk, $y_{\min }$ and $y_{\max }$ 
TABLe 1: Cases lists for the identification of social risks.

\begin{tabular}{|c|c|c|c|c|c|}
\hline No. & $\begin{array}{l}\text { Time for } \\
\text { social risks }\end{array}$ & Name for social risk events & Project name & Social risk factors & Related stakeholders \\
\hline 1 & 2015.6 & $\begin{array}{c}\text { Jinshan "PX" incident in } \\
\text { Shanghai }\end{array}$ & PX project & $\begin{array}{l}\text { Environmental pollution, public } \\
\text { opinion/rumor, poor credibility } \\
\text { of government }\end{array}$ & $\begin{array}{c}\text { Government, residents, media, } \\
\text { public }\end{array}$ \\
\hline 2 & 2014.10 & $\begin{array}{l}\text { Jinning incident in Yunnan } \\
\text { Province }\end{array}$ & $\begin{array}{l}\text { Business logistics } \\
\text { center }\end{array}$ & $\begin{array}{l}\text { Unfair compensation for } \\
\text { housing demolition and land } \\
\text { requisition, violation of laws } \\
\text { and rules, government's lax/ } \\
\text { improper administration }\end{array}$ & $\begin{array}{l}\text { Residents, contractor, project } \\
\text { developer }\end{array}$ \\
\hline 3 & 2014.3 & $\begin{array}{l}\text { Putian incident in Fujian } \\
\text { Province }\end{array}$ & $\begin{array}{l}\text { Chemical } \\
\text { industrial }\end{array}$ & $\begin{array}{l}\text { Environmental pollution (water } \\
\text { and land), violation of laws and } \\
\text { rules, disturbance of local } \\
\text { residents }\end{array}$ & $\begin{array}{l}\text { Residents, government, project } \\
\text { developer }\end{array}$ \\
\hline 4 & 2014.3 & $\begin{array}{l}\text { Maoming "PX" incident in } \\
\text { Guangdong Province }\end{array}$ & PX project & $\begin{array}{c}\text { Environmental pollution, } \\
\text { insufficient information } \\
\text { exchange among different } \\
\text { stakeholders, negative attitudes } \\
\text { of local residents, violation of } \\
\text { laws and rules }\end{array}$ & $\begin{array}{l}\text { Residents, government, police } \\
\text { station }\end{array}$ \\
\hline 5 & 2013.5 & $\begin{array}{c}\text { Kunming "PX" Incident in } \\
\text { Yunnan Province }\end{array}$ & PX project & $\begin{array}{l}\text { Environmental pollution, } \\
\text { insufficient information } \\
\text { exchange among different } \\
\text { stakeholders, negative attitudes } \\
\text { of local residents, disturbance of } \\
\text { local residents }\end{array}$ & Residents, government, media \\
\hline 6 & 2012.1 & $\begin{array}{l}\text { Ningbo "PX" incident in } \\
\text { Zhejiang Province }\end{array}$ & PX project & $\begin{array}{l}\text { Environmental pollution, } \\
\text { insufficient information } \\
\text { exchange among different } \\
\text { stakeholders, negative attitudes } \\
\text { of local residents, disturbance of } \\
\text { local residents }\end{array}$ & $\begin{array}{l}\text { Residents, government, police } \\
\text { station, media }\end{array}$ \\
\hline 7 & 2012.7 & $\begin{array}{l}\text { Qidong incident in Jiangsu } \\
\text { Province }\end{array}$ & $\begin{array}{l}\text { Nantong sea } \\
\text { drainage project }\end{array}$ & $\begin{array}{l}\text { Environmental pollution, } \\
\text { insufficient information } \\
\text { exchange, negative attitudes of } \\
\text { local residents, disturbance of } \\
\text { local residents, violation of laws } \\
\text { and rules, media dissemination }\end{array}$ & $\begin{array}{l}\text { Residents, government, police } \\
\text { station, media }\end{array}$ \\
\hline 8 & 2012.7 & $\begin{array}{c}\text { Shifang incident in Sichuan } \\
\text { Province }\end{array}$ & $\begin{array}{l}\text { Chemical } \\
\text { industrial }\end{array}$ & $\begin{array}{l}\text { Environmental pollution, } \\
\text { negative attitudes of local } \\
\text { residents, disturbance of local } \\
\text { residents, violation of laws and } \\
\text { rules, public opinion/rumor, } \\
\text { media dissemination }\end{array}$ & $\begin{array}{c}\text { Residents, government, public, } \\
\text { media }\end{array}$ \\
\hline 9 & 2011.12 & $\begin{array}{l}\text { Haimen incident in } \\
\text { Guangdong Province }\end{array}$ & Power plant & $\begin{array}{l}\text { Environmental pollution, } \\
\text { insufficient information } \\
\text { exchange, negative attitudes of } \\
\text { local residents, disturbance of } \\
\text { local residents, violation of laws } \\
\text { and rules, media dissemination }\end{array}$ & $\begin{array}{l}\text { Residents, government, police } \\
\text { station, media }\end{array}$ \\
\hline 10 & 2011.9 & $\begin{array}{l}\text { Haining incident in Zhejiang } \\
\text { Province }\end{array}$ & $\begin{array}{l}\text { Solar energy } \\
\text { enterprises }\end{array}$ & $\begin{array}{l}\text { Environmental pollution, } \\
\text { violation of laws and rules, } \\
\text { media dissemination }\end{array}$ & $\begin{array}{l}\text { Residents, government, police } \\
\text { station }\end{array}$ \\
\hline 11 & 2011.8 & $\begin{array}{l}\text { Dalian "PX" incident in } \\
\text { Liaoning Province }\end{array}$ & PX project & $\begin{array}{l}\text { Environmental pollution, } \\
\text { insufficient information } \\
\text { exchange, negative attitudes of } \\
\text { local residents, disturbance of } \\
\text { local residents }\end{array}$ & $\begin{array}{l}\text { Residents, government, media, } \\
\text { police station }\end{array}$ \\
\hline
\end{tabular}


TABLE 1: Continued.

\begin{tabular}{|c|c|c|c|c|c|}
\hline No. & $\begin{array}{l}\text { Time for } \\
\text { social risks }\end{array}$ & Name for social risk events & Project name & Social risk factors & Related stakeholders \\
\hline 12 & 2010.10 & $\begin{array}{l}\text { Cangwu incident in Guangxi } \\
\text { Province }\end{array}$ & $\begin{array}{l}\text { Developing } \\
\text { leisure tourism }\end{array}$ & $\begin{array}{c}\text { Insufficient information } \\
\text { exchange among different } \\
\text { stakeholders, negative attitudes } \\
\text { of local residents, disturbance of } \\
\text { local residents }\end{array}$ & Residents, government \\
\hline 13 & 2010.7 & $\begin{array}{c}\text { Tong'an incident in Jiangsu } \\
\text { Province }\end{array}$ & $\begin{array}{l}\text { Industrial park } \\
\text { project }\end{array}$ & $\begin{array}{l}\text { Unfair compensation for } \\
\text { housing demolition and land } \\
\text { requisition, government's lax/ } \\
\text { improper administration }\end{array}$ & Residents, government \\
\hline 14 & 2007.6 & $\begin{array}{c}\text { Xiamen "PX" incident in } \\
\text { Fujian Province }\end{array}$ & PX project & $\begin{array}{l}\text { Environmental pollution, } \\
\text { insufficient information } \\
\text { exchange, negative attitudes of } \\
\text { local residents, disturbance of } \\
\text { local residents, violation of laws } \\
\text { and rules, public opinion/rumor }\end{array}$ & $\begin{array}{l}\text { Residents, government, media, } \\
\text { public, police station }\end{array}$ \\
\hline 15 & 2005.4 & $\begin{array}{l}\text { Dongyang incident in } \\
\text { Zhejiang Province }\end{array}$ & $\begin{array}{l}\text { Chemical } \\
\text { industrial park }\end{array}$ & $\begin{array}{c}\text { Environmental pollution, } \\
\text { government's lax/improper } \\
\text { administration, violation of laws } \\
\text { and rules }\end{array}$ & $\begin{array}{l}\text { Residents, government, } \\
\text { supervisor }\end{array}$ \\
\hline
\end{tabular}

denote the minimum and maximum value of IRL, respectively, and $y_{n}$ is the normalized value.

\section{Step 4. Determining CSRFs.}

We consider the risk factors with normalized integrated risk value equal to or greater than 0.50 as critical factors. This selection mechanism follows a similar approach adopted in the previous study $[21,28,29,31]$. In this way, 18 factors were chosen for the following analysis, and they were classified into four categories (see Table 4).

\section{Social Risk Assessment with Fuzzy Synthetic Theory}

5.1. Fuzzy Synthetic Assessment (FSA) Method. Fuzzy set theory, which was introduced by Zadeh in 1965, defines fuzzy numbers that have the ability of quantifying subjective linguistic terms (such as very rare, rare, low, moderate, frequent, very frequent, and absolutely certain). FSA, which combines fuzzy theory with the multiple attribute decisionmaking method, is a branch of fuzzy set theory and can effectively handle the fuzziness of data involved in decisionmaking [28]. In recent years, the fuzzy synthetic assessment method is widely employed in risk assessment. Xu et al. [21] determined 17 critical risk factors and six critical risk groups for PPP projects in China through a questionnaire survey and developed a risk synthetic assessment model. With FSA method, Ameyaw and chan [32] assessed the overall risks of public-private partnership water supply projects in developing countries and confirmed that financial/commercial risk category is the most critical principal factor. Wu et al. [31] explored risk factors for straw-based power generation public-private partnership projects in China through a questionnaire survey and evaluated the risk level using the FSA method. Despite the wide applications, it is rare in the literature to assess the social risk of MCPs under uncertain conditions; FSA is an effective method to handle this problem.

5.2. Social Risk Synthetic Assessment Based on Fuzzy Theory. In this section, in order to assess the overall social risk level for MCPs, large hydraulic engineering projects were selected as illustration cases for developing a fuzzy risk evaluation model. The detailed steps are summarized as follows.

5.2.1. Quantification of Language Variables for the CSRFs. According to fuzzy theory, the linguistic information can be translated into appropriate fuzzy numbers. Therefore, we quantified experts' linguistic terms (such as absolutely low, very low, low, moderate, high, very high, and absolutely high) through the following equation (see [21, 31, 32]):

$$
\mathrm{MF}_{d_{i j}}=\frac{x_{1 d_{i j}}}{\mathrm{AL}}+\frac{x_{2 d_{i j}}}{\mathrm{VL}}+\frac{x_{3 d_{i j}}}{\mathrm{~L}}+\frac{x_{4 d_{i j}}}{\mathrm{M}}+\frac{x_{5 d_{i j}}}{\mathrm{H}}+\frac{x_{6 d_{i j}}}{\mathrm{VH}}+\frac{x_{7 d_{i j}}}{\mathrm{AH}},
$$

where $d_{i j}$ denotes the $j$ th risk factor of the $i$ th $\left(i=c_{1}\right.$, $\left.c_{2}, \ldots, c_{6}\right)$ CSRG; $M F_{d_{i j}}$ represents the membership function of a certain risk factor $d_{i j}$; and $x_{k d_{i j}}(k=1,2, \ldots, 7)$ is the percentage of the experts who scored $j$ for PO and MI of the risk factor $d_{i j}$, which is the degree of membership function. Equation (2) can also be written as follows:

$$
\mathrm{MF}_{d_{i j}}=\left(x_{1 d_{i j}}, x_{2 d_{i j}}, x_{3 d_{i j}}, x_{4 d_{i j}}, x_{5 d_{i j}}, x_{6 d_{i j}}, x_{7 d_{i j}}\right) \text {, }
$$

and $\mathrm{MF}_{d_{i j}}$ satisfies $\quad \sum_{k=1}^{7} x_{k d_{i j}}=1$. For example, $\mathrm{MF}_{p d_{11}}=(0,0,0.125,0.125,0.5,0.0625,0.1875)$ represents the membership function of a certain risk factor $d_{11}$ regarding $\mathrm{PO}$. 
TABLE 2: Ranking of social risk factors based on the questionnaire results.

\begin{tabular}{|c|c|c|c|c|c|c|c|}
\hline Social risk factors & $\mathrm{PO}$ & MI & IRL & Rank & $\begin{array}{l}\text { Normalized } \\
\text { values }\end{array}$ & Sources & Stakeholders \\
\hline $\begin{array}{l}\text { Unfair compensation for housing } \\
\text { demolition and land requisition }\end{array}$ & 5.06 & 5.44 & 5.25 & 1 & 1.00 & {$[1,3,4,18,26,28,29]$} & $\begin{array}{l}\text { Government/residents/ } \\
\text { contractor/owner }\end{array}$ \\
\hline Poor credibility of government & 5.13 & 4.94 & 5.03 & 2 & 0.90 & {$[4,6]$} & $\begin{array}{l}\text { Government/residents/owner/ } \\
\text { contractor/community }\end{array}$ \\
\hline Forced demolition & 4.75 & 5.25 & 4.99 & 3 & 0.89 & {$[4,18]$} & $\begin{array}{c}\text { Government/residents/ } \\
\text { contractor }\end{array}$ \\
\hline Engineering quality problems & 4.81 & 5.00 & 4.91 & 4 & 0.85 & {$[4,13,18]$} & $\begin{array}{l}\text { Government/contractor/ } \\
\text { owner/supervisor }\end{array}$ \\
\hline Violation of laws and rules & 4.63 & 4.94 & 4.78 & 5 & 0.79 & {$[4,18]$} & $\begin{array}{l}\text { Government/residents/ } \\
\text { contractor }\end{array}$ \\
\hline Disturbance of local residents & 4.81 & 4.69 & 4.75 & 6 & 0.78 & [6] & Government/residents \\
\hline $\begin{array}{l}\text { Government's improper } \\
\text { administration }\end{array}$ & 4.69 & 4.81 & 4.75 & 7 & 0.78 & {$[1,3,4,11]$} & Government/residents \\
\hline $\begin{array}{l}\text { Environment pollution (water, land, } \\
\text { noise, etc.) }\end{array}$ & 5.06 & 4.44 & 4.74 & 8 & 0.78 & {$[1,3,4,6,14,28,30]$} & $\begin{array}{c}\text { Government/contractor/ } \\
\text { residents/supervisor/ } \\
\text { community }\end{array}$ \\
\hline Unreasonable relocation & 4.69 & 4.75 & 4.72 & 9 & 0.77 & {$[1,3,4,11]$} & Residents/contractor \\
\hline Security hidden danger & 4.50 & 4.75 & 4.62 & 10 & 0.72 & {$[3,4,11,18,19,26]$} & $\begin{array}{l}\text { Government/residents/ } \\
\text { contractor/ owner/supervisor }\end{array}$ \\
\hline $\begin{array}{l}\text { Negative attitudes of local residents } \\
\text { towards project }\end{array}$ & 4.56 & 4.50 & 4.53 & 11 & 0.68 & {$[1,3,4,11]$} & Government/residents \\
\hline Lack of funds & 4.94 & 4.13 & 4.51 & 12 & 0.67 & {$[3,4,11,26]$} & Government/owner/contractor \\
\hline $\begin{array}{l}\text { Lack of information on key } \\
\text { stakeholders' interests }\end{array}$ & 4.63 & 4.06 & 4.34 & 13 & 0.60 & {$[3,4,11]$} & $\begin{array}{c}\text { Government/residents/ } \\
\text { contractor/ owner/supervisor }\end{array}$ \\
\hline $\begin{array}{l}\text { Variations in policies or compensation } \\
\text { standards }\end{array}$ & 4.25 & 4.19 & 4.22 & 14 & 0.54 & {$[1,18]$} & Supplier/contractor \\
\hline Decision-maker moral & 4.19 & 4.13 & 4.16 & 15 & 0.52 & {$[3,4,11]$} & $\begin{array}{l}\text { Government/contractor/ } \\
\text { owner/supervisor }\end{array}$ \\
\hline Media dissemination & 4.13 & 4.13 & 4.13 & 16 & 0.50 & & Residents/media/public \\
\hline Unemployment problem & 4.19 & 4.06 & 4.13 & 17 & 0.50 & {$[3,4,26]$} & $\begin{array}{c}\text { Residents/contractor/ } \\
\text { supervisor }\end{array}$ \\
\hline Decision-maker competence & 3.94 & 4.31 & 4.12 & 18 & 0.50 & [1] & $\begin{array}{c}\text { Government/residents/ } \\
\text { contractor/owner/supervisor }\end{array}$ \\
\hline Public opinion/rumor & 4.00 & 4.13 & 4.06 & 19 & 0.47 & {$[4,6,18]$} & $\begin{array}{l}\text { Residents/contractor/ } \\
\text { community }\end{array}$ \\
\hline Unreasonable project design & 3.94 & 3.94 & 3.94 & 20 & 0.42 & {$[1,4,6]$} & Design institute/contractor \\
\hline $\begin{array}{l}\text { Insufficient protection for vulnerable } \\
\text { groups }\end{array}$ & 3.81 & 3.88 & 3.84 & 21 & 0.38 & {$[1,3,4,26]$} & N/A \\
\hline Cost overrun & 3.88 & 3.69 & 3.78 & 22 & 0.35 & {$[1,4,11,18,19]$} & Government/owner/contractor \\
\hline Road occupancy/traffic disruption & 4.00 & 3.56 & 3.78 & 23 & 0.35 & {$[1,3,4,18]$} & $\begin{array}{c}\text { Residents/contractor/ } \\
\text { community }\end{array}$ \\
\hline Improper drawing & 3.75 & 3.75 & 3.75 & 24 & 0.34 & {$[1,4,6,26]$} & $\begin{array}{c}\text { Design institute/contractor/ } \\
\text { owner }\end{array}$ \\
\hline $\begin{array}{l}\text { Enterprises losses caused by land } \\
\text { acquisition }\end{array}$ & 3.81 & 3.69 & 3.75 & 25 & 0.34 & {$[3,4,18]$} & $\begin{array}{l}\text { Government/ enterprises/ } \\
\text { residents }\end{array}$ \\
\hline Unreasonable feasibility studies & 4.06 & 3.44 & 3.74 & 26 & 0.33 & {$[1,4,17]$} & Design institute \\
\hline Conflict of construction projects & 3.69 & 3.69 & 3.69 & 27 & 0.31 & {$[4,6,11,18,26]$} & Contractor/owner \\
\hline Error in construction site investigation & 3.69 & 3.69 & 3.69 & 28 & 0.31 & {$[11,18]$} & Contractor/owner \\
\hline Project schedule delays & 3.75 & 3.63 & 3.69 & 29 & 0.31 & {$[1,4,11,14]$} & Government/contractor/owner \\
\hline $\begin{array}{l}\text { Lack of skill and experience of } \\
\text { construction workers }\end{array}$ & 3.63 & 3.63 & 3.63 & 30 & 0.28 & {$[1,4,6,26]$} & $\begin{array}{l}\text { Government/residents/ } \\
\text { contractor/owner }\end{array}$ \\
\hline Cultural conflicts & 3.50 & 3.75 & 3.62 & 31 & 0.28 & {$[1,3,4,17,26]$} & Contractor/designer \\
\hline Financial crisis & 3.38 & 3.69 & 3.53 & 32 & 0.24 & {$[4,14]$} & Government/contractor \\
\hline Rising consumer prices & 2.88 & 3.81 & 3.31 & 33 & 0.14 & {$[1,18]$} & $\begin{array}{l}\text { Government/residents/ } \\
\text { contractor }\end{array}$ \\
\hline Ineffective waste disposal & 3.38 & 3.13 & 3.25 & 34 & 0.11 & {$[3,4,11,18]$} & $\begin{array}{l}\text { Residents/contractor/ } \\
\text { supervisor }\end{array}$ \\
\hline $\begin{array}{l}\text { Uncertainties in weather and } \\
\text { environment }\end{array}$ & 2.81 & 3.19 & 2.99 & 35 & 0.00 & {$[1,3,4,26]$} & N/A \\
\hline
\end{tabular}


TABLE 3: Information of experts.

\begin{tabular}{lcc}
\hline & $n$ & $\%$ \\
\hline Role & 1 & \\
Government & 2 & 6 \\
Project manager & 5 & 13 \\
Design institute & 8 & 31 \\
Institute of higher education & & 50 \\
\hline Title/education & 4 & \\
Professor & 5 & 25 \\
Associate professor & 9 & 31 \\
Ph.D. & 5 & 56 \\
Master & 2 & 31 \\
Bachelor & & 13 \\
\hline
\end{tabular}

TABLE 4: Critical risk factors and stakeholders.

\begin{tabular}{lc}
\hline Categories/groups & Social risk factors \\
\hline Unfair compensation for housing \\
Policy/legal $\left(c_{1}\right)$ & Forced demolition $\left(d_{12}\right)$ \\
& Violation of laws and rules $\left(d_{13}\right)$ \\
Unreasonable relocation $\left(d_{14}\right)$ \\
Variations in policies or compensation \\
standards $\left(d_{15}\right)$
\end{tabular}

5.2.2. Determination of Weightings for the CSRFs and CSRGs. We defined the weightings for each of the 18 CSRFs and 6 CSRGs using the following equation:

$$
\omega_{i}=\frac{m_{i}}{\sum_{i=1}^{x} m_{i}}
$$

where $\omega_{i}$ denotes the weighting function of a particular CSRF or CSRG concerning the PO and MI; $m_{i}$ represents the mean value of a CSRF or CSRG from the questionnaire; and $x$ is the number of elements.

The weighting vector can be expressed as follows:

$$
W_{i}=\left(\omega_{1}, \omega_{2}, \ldots, \omega_{i}\right) .
$$

Results are shown in Table 5.

5.2.3. Establishment of Social Risk FSA Model. This section consists of three steps. The first step deals with the assessment on the intragroup factors. The second step deals with the assessment on the intergroup factors. The third step deals with the overall risk assessment on the project.

Step 1. According to equation (2), the fuzzy degree of membership matrix regarding ith CSRGs (probability or severity) is written as follows:

$M_{c_{i}}=\left(\begin{array}{c}M_{d_{i 1}} \\ M_{d_{i 2}} \\ \vdots \\ M_{d_{i n}}\end{array}\right)=\left(\begin{array}{ccccccc}x_{1 d_{i 1}} & x_{2 d_{i 1}} & x_{3 d_{i 1}} & x_{4 d_{i 1}} & x_{5 d_{i 1}} & x_{6 d_{i 1}} & x_{7 d_{i 1}} \\ x_{1 d_{i 2}} & x_{2 d_{i 2}} & x_{3 d_{i 2}} & x_{4 d_{i 2}} & x_{5 d_{i 2}} & x_{6 d_{i 2}} & x_{7 d_{i 2}} \\ \ldots & \ldots & \ldots & \ldots & \ldots & \ldots & \ldots \\ x_{1 d_{i n}} & x_{2 d_{i n}} & x_{3 d_{i n}} & x_{4 d n} & x_{5 d_{i n}} & x_{6 d_{i n}} & x_{7 d_{i n}}\end{array}\right)$.

Then, the fuzzy assessment matrix $F_{c_{i}}$ can be obtained using the weighting vector and the membership function of the CSRFs within a CSRG to do fuzzy synthesis computation:

$$
\begin{aligned}
F_{c_{i}}= & W_{c_{i}} \cdot M_{c_{i}}=\left(\begin{array}{llllll}
f_{i 1} & f_{i 2} & \cdots & f_{i 7}
\end{array}\right) \\
= & \left(\begin{array}{lllllll}
\omega_{i 1} & \omega_{i 2} & \cdots & \omega_{i n}
\end{array}\right) \\
& \cdot\left(\begin{array}{ccccccc}
x_{1 d_{i 1}} & x_{2 d_{i 1}} & x_{3 d_{i 1}} & x_{4 d_{i 1}} & x_{5 d_{i 1}} & x_{6 d_{i 1}} & x_{7 d_{i 1}} \\
x_{1 d_{i 2}} & x_{2 d_{i 2}} & x_{3 d_{i 2}} & x_{4 d_{i 2}} & x_{5 d_{i 2}} & x_{6 d_{i 2}} & x_{7 d_{i 2}} \\
\cdots & \cdots & \cdots & \cdots & \cdots & \cdots & \cdots \\
x_{1 d_{i n}} & x_{2 d_{i n}} & x_{3 d_{i n}} & x_{4 d n} & x_{5 d_{i n}} & x_{6 d_{i n}} & x_{7 d_{i n}}
\end{array}\right),
\end{aligned}
$$

where $f_{\text {in }}$ is the degree of membership of the ith CSRGs and the symbol "." is the fuzzy composite operation (see $[21,29,32])$, and it can be represented by the following formula:

$$
f_{i k}=\min \left\{1, \sum_{j=1}^{n} \omega_{i j} x_{k d_{i j}}\right\}, \quad k=1,2, \ldots, 7 .
$$

Results are shown in Table 6.

Step 2. The following evaluation matrix can be obtained:

$$
F=\left(\begin{array}{c}
F_{c_{1}} \\
\vdots \\
F_{c_{i}}
\end{array}\right)=\left(\begin{array}{cccc}
f_{11} & f_{12} & \cdots & f_{17} \\
\cdots & \cdots & \cdots & \cdots \\
f_{i 1} & f_{i 2} & \cdots & f_{i 7}
\end{array}\right), \quad i=6 .
$$

Similarly to Step 1, we can obtain $S$ that can assess the overall project social risk:

$$
\begin{aligned}
S= & W \cdot F=\left(\omega_{1} \cdots \omega_{i}\right) \\
& \cdot\left(\begin{array}{cccc}
f_{11} & f_{12} & \cdots & f_{17} \\
\cdots & \cdots & \cdots & \cdots \\
f_{i 1} & f_{i 2} & \cdots & f_{i 7}
\end{array}\right), \quad i=6, \\
= & \left(\begin{array}{lll}
s_{1} & \cdots & s_{7}
\end{array}\right),
\end{aligned}
$$

where $S$ is the degree of membership of the overall social risk of project regarding risk probability $(p)$ or impact level (l), and it can be quantified by using the following equation: 
TABLE 5: Weight of CSRFs and CSRGs.

\begin{tabular}{|c|c|c|c|c|c|c|c|c|c|}
\hline \multirow[b]{2}{*}{ Categories/groups } & \multirow[b]{2}{*}{ Social risk factors } & \multicolumn{4}{|c|}{$\mathrm{PO}$} & \multicolumn{4}{|c|}{ MI } \\
\hline & & Value & $\begin{array}{l}\text { Factor } \\
\text { weight }\end{array}$ & $\begin{array}{l}\text { Group } \\
\text { value }\end{array}$ & $\begin{array}{l}\text { Group } \\
\text { weight }\end{array}$ & Value & $\begin{array}{l}\text { Factor } \\
\text { weight }\end{array}$ & $\begin{array}{l}\text { Group } \\
\text { value }\end{array}$ & $\begin{array}{l}\text { Group } \\
\text { weight }\end{array}$ \\
\hline \multirow{5}{*}{ Policy/legal $\left(c_{1}\right)$} & \multirow{5}{*}{$\begin{array}{c}\text { Unfair compensation for housing } \\
\text { demolition and land requisition }\left(d_{11}\right) \\
\text { Forced demolition }\left(d_{12}\right) \\
\text { Violation of laws and rules }\left(d_{13}\right) \\
\text { Unreasonable relocation }\left(d_{14}\right) \\
\text { Variations in policies or compensation } \\
\text { standards }\left(d_{15}\right)\end{array}$} & 5.06 & 0.22 & \multirow[t]{5}{*}{23.38} & \multirow[t]{5}{*}{0.29} & 5.44 & 0.22 & \multirow[t]{5}{*}{24.57} & \multirow[t]{5}{*}{0.3} \\
\hline & & 4.75 & 0.21 & & & 5.25 & 0.22 & & \\
\hline & & 4.63 & 0.2 & & & 4.94 & 0.2 & & \\
\hline & & 4.69 & 0.2 & & & 4.75 & 0.19 & & \\
\hline & & 4.25 & 0.18 & & & 4.19 & 0.17 & & \\
\hline \multirow{5}{*}{ Society $\left(c_{2}\right)$} & Poor credibility of government $\left(d_{21}\right)$ & 5.13 & 0.22 & \multirow[t]{5}{*}{22.82} & \multirow[t]{5}{*}{0.28} & 4.94 & 0.22 & \multirow[t]{5}{*}{22.32} & \multirow[t]{5}{*}{0.27} \\
\hline & Disturbance of local residents $\left(d_{22}\right)$ & 4.81 & 0.21 & & & 4.69 & 0.21 & & \\
\hline & $\begin{array}{l}\text { Negative attitudes of local residents } \\
\text { towards project }\left(d_{23}\right)\end{array}$ & 4.56 & 0.2 & & & 4.5 & 0.2 & & \\
\hline & Media dissemination $\left(d_{24}\right)$ & 4.13 & 0.18 & & & 4.13 & 0.19 & & \\
\hline & Unemployment problem $\left(d_{25}\right)$ & 4.19 & 0.18 & & & 4.06 & 0.18 & & \\
\hline Environment $\left(c_{3}\right)$ & $\begin{array}{l}\text { Environment pollution (water, land, } \\
\text { noise, etc.) }\left(d_{31}\right)\end{array}$ & 5.06 & 1 & 5.06 & 0.06 & 4.44 & 1 & 4.44 & 0.06 \\
\hline Finance $\left(c_{4}\right)$ & Lack of funds $\left(d_{41}\right)$ & 4.94 & 1 & 4.94 & 0.06 & 4.13 & 1 & 4.13 & 0.05 \\
\hline Project/technique $\left(c_{5}\right)$ & Engineering quality problems $\left(d_{51}\right)$ & 4.81 & 1 & 4.81 & 0.06 & 5 & 1 & 5 & 0.06 \\
\hline \multirow{5}{*}{$\begin{array}{l}\text { Organization/ } \\
\text { management }\left(c_{6}\right)\end{array}$} & $\begin{array}{l}\text { Government's improper } \\
\text { administration }\left(d_{61}\right)\end{array}$ & 4.69 & 0.21 & \multirow[t]{5}{*}{21.95} & \multirow[t]{5}{*}{0.26} & 4.81 & 0.22 & \multirow[t]{5}{*}{22.06} & \multirow[t]{5}{*}{0.27} \\
\hline & Security hidden danger $\left(d_{62}\right)$ & 4.5 & 0.21 & & & 4.75 & 0.22 & & \\
\hline & $\begin{array}{l}\text { Lack of information on key stakeholders' } \\
\text { interests }\left(d_{63}\right)\end{array}$ & 4.63 & 0.21 & & & 4.06 & 0.18 & & \\
\hline & Decision-maker moral $\left(d_{64}\right)$ & 4.19 & 0.19 & & & 4.13 & 0.19 & & \\
\hline & Decision-maker competence $\left(d_{65}\right)$ & 3.94 & 018 & & & 4.31 & 0.19 & & \\
\hline Sum & & & & 82.96 & & & & 82.52 & \\
\hline
\end{tabular}

$$
\operatorname{IRL}_{p(l)}=\sum_{k=1}^{7} k s_{k} .
$$

Results are shown in Table 7.

Step 3. We obtained not only the integrated risk index of each risk group, but also the overall risk index of the project using equation (12). Moreover, we can rank CSRGs according to IRL index (See Table 8);

$$
\mathrm{IRL}=\sqrt{\mathrm{IRL}_{p} \times \mathrm{IRL}_{l}}
$$

5.2.4. Conclusion of Social Risk FSA Model. Through wideranging literature resources and case studies, we identified 35 social risk factors and related stakeholders. After a questionnaire survey and calculation of the probability and impact for risk factors, 18 critical social risk factors were determined and were classified into six groups (CSRGs), that is policy/ legal $\left(c_{1}\right)$, society $\left(c_{2}\right)$, environment $\left(c_{3}\right)$, finance $\left(c_{4}\right)$, project/ technique $\left(c_{5}\right)$, and organization/management $\left(c_{6}\right)$.

As seen from Table 2, unfair compensation for housing demolition and land requisition ranked the top with score 5.25 that was between "high" and "very high". It was followed by poor credibility of government, forced demolition, engineering quality problems, violation of laws and rules, disturbance of local residents, government's improper administration, unreasonable relocation, and security hidden danger. The IRL of these risks is greater than 4.6, and they need to be specially noticed. Moreover, these factors have already been discussed and considered as the most crucial risk factors for construction projects in some literatures (see $[3,4,18])$. Liu et al. [2] pointed out land acquisition and house demolition risks (such as unfair land acquisition compensation standard, compensation supporting measures, demolition compensation standard, and unreasonable resettlement arrangement) were high social risk factors. The results implicated both governments and decision makers should have paid more attention to the top 10 risk factors.

The summary results of social risk FSA are shown in Table 7 which manifested the mean value of probability and severity, the IRL of critical risk groups, risk ranking, and the overall project risk index. From Table 7 , we can obtain the overall risk index of the MCPs in China as 4.65, which is between moderate and high. As for the risk groups, the policy/legal risk ranked first with an integrated risk rating of 5.2, which is high risk. The following CSRGs are project/ technique, environment, society, finance, and organization/ management with the overall risk index 4.93, 4.76, 4.54, 4.51, and 4.47 , respectively. In summary, the overall social risk level of the MCPs in China is slightly higher. The policy/legal risk and project/technique risk are high.

5.2.5. Comparison Analysis. In order to explore the additional results of fuzzy logic, a comparison analysis between the results obtained by the fuzzy logic and the results of Table 2 was conducted. The detailed steps were summarized as follows. 
TABle 6: Membership function of CSRFs and CSRGs for PO and MI.

\begin{tabular}{|c|c|c|c|c|c|c|c|}
\hline \multirow[b]{2}{*}{$\begin{array}{l}\text { Categories/ } \\
\text { groups }\end{array}$} & \multirow[b]{2}{*}{ Social risk factors } & \multicolumn{3}{|c|}{$\mathrm{PO}$} & \multicolumn{3}{|c|}{ MI } \\
\hline & & Weight & $\begin{array}{c}\text { Membership } \\
\text { function of CSRFs }\end{array}$ & $\begin{array}{l}\text { Membership } \\
\text { function of } \\
\text { CSRGs }\end{array}$ & Weight & $\begin{array}{c}\text { Weight } \\
\text { membership } \\
\text { function of CSRFs }\end{array}$ & $\begin{array}{l}\text { Membership } \\
\text { function of } \\
\text { CSRGs }\end{array}$ \\
\hline \multirow{5}{*}{$\begin{array}{l}\text { Policy/legal } \\
\left(c_{1}\right)\end{array}$} & $\begin{array}{l}\text { Unfair compensation for } \\
\text { housing demolition and } \\
\text { land requisition }\left(d_{11}\right)\end{array}$ & 0.22 & $\begin{array}{c}(0,0,0.13,0.13 \\
0.5,0.06,0.19)\end{array}$ & \multirow{5}{*}{$\begin{array}{c}(0.02,0.04 \\
0.13,0.17,0.36 \\
0.16,0.1)\end{array}$} & 0.22 & $\begin{array}{c}(0,0.06,0,0,0.56 \\
0.13,0.25)\end{array}$ & \multirow{5}{*}{$\begin{array}{c}(0.01,0.06,0.06 \\
0.19,0.35,0.19 \\
0.14)\end{array}$} \\
\hline & Forced demolition $\left(d_{12}\right)$ & 0.21 & $\begin{array}{c}(0,0.06,0.25,0.06, \\
0.31,0.13,0.19)\end{array}$ & & 0.22 & $\begin{array}{c}(0,0.06,0,0.25 \\
0.19,0.31,0.19)\end{array}$ & \\
\hline & $\begin{array}{c}\text { Violation of laws and } \\
\text { rules }\left(d_{13}\right)\end{array}$ & 0.2 & $\begin{array}{c}(0.06,0,0.06,0.25 \\
0.38,0.25,0)\end{array}$ & & 0.2 & $\begin{array}{l}(0.06,0,0,0.25 \\
0.31,0.31,0.06)\end{array}$ & \\
\hline & $\begin{array}{l}\text { Unreasonable relocation } \\
\qquad\left(d_{14}\right)\end{array}$ & 0.2 & $\begin{array}{c}(0,0.06,0.19,0.13 \\
0.31,0.25,0.06)\end{array}$ & & 0.19 & $\begin{array}{c}(0,0.06,0.13,0.19 \\
0.38,0.13,0.13)\end{array}$ & \\
\hline & $\begin{array}{c}\text { Variations in policies or } \\
\text { compensation } \\
\text { standards }\left(d_{15}\right)\end{array}$ & 0.18 & $\begin{array}{c}(0.06,0.06,0.13 \\
0.31,0.25,0.13 \\
0.06)\end{array}$ & & 0.17 & $\begin{array}{c}(0,0.13,0.19,0.25, \\
0.31,0.06,0.06)\end{array}$ & \\
\hline \multirow{5}{*}{ Society $\left(c_{2}\right)$} & $\begin{array}{l}\text { Poor credibility of } \\
\text { government }\left(d_{21}\right)\end{array}$ & 0.22 & $\begin{array}{c}(0,0.06,0.13,0.06 \\
0.31,0.25,0.19)\end{array}$ & \multirow{5}{*}{$\begin{array}{c}(0,0.07,0.13 \\
0.27,0.25 \\
0.19,0.08)\end{array}$} & 0.22 & $\begin{array}{l}(0,0,0.13,0.19 \\
0.38,0.25,0.06)\end{array}$ & \multirow{5}{*}{$\begin{array}{l}(0,0.06,0.14 \\
0.26,0.37,0.17 \\
0.01)\end{array}$} \\
\hline & $\begin{array}{l}\text { Disturbance of local } \\
\text { residents }\left(d_{22}\right)\end{array}$ & 0.21 & $\begin{array}{c}(0,0.06,0.06,0.38 \\
0.13,0.25,0.13)\end{array}$ & & 0.21 & $\begin{array}{c}(0,0.06,0.13,0.13, \\
0.44,0.25,0)\end{array}$ & \\
\hline & $\begin{array}{l}\text { Negative attitudes of } \\
\text { local residents towards } \\
\text { project }\left(d_{23}\right)\end{array}$ & 0.2 & $\begin{array}{c}(0,0.06,0.06,0.38 \\
0.25,0.25,0)\end{array}$ & & 0.2 & $\begin{array}{c}(0,0.06,0.06,0.31 \\
0.44,0.13,0)\end{array}$ & \\
\hline & $\begin{array}{c}\text { Media } \\
\text { dissemination }\left(d_{24}\right)\end{array}$ & 0.18 & $\begin{array}{c}(0,0.13,0.13,0.38 \\
0.25,0.13,0)\end{array}$ & & 0.19 & $\begin{array}{c}(0,0.13,0.13,0.38 \\
0.25,0.13,0)\end{array}$ & \\
\hline & $\begin{array}{l}\text { Unemployment } \\
\text { problem }\left(d_{25}\right)\end{array}$ & 0.18 & $\begin{array}{c}(0,0.06,0.31,0.19, \\
0.31,0.06,0.06)\end{array}$ & & 0.18 & $\begin{array}{c}(0,0.06,0.25,0.31, \\
0.31,0.06,0)\end{array}$ & \\
\hline $\begin{array}{l}\text { Environment } \\
\left(c_{3}\right)\end{array}$ & $\begin{array}{c}\text { Environment pollution } \\
\text { (water, land, } \\
\text { noise, etc.) }\left(d_{31}\right)\end{array}$ & 1 & $\begin{array}{c}(0,0.06,0.06,0.13 \\
0.31,0.38,0.06)\end{array}$ & $\begin{array}{c}(0,0.06,0.06 \\
0.13,0.31 \\
0.38,0.06) \\
\end{array}$ & 1 & $\begin{array}{l}0,0.13,0.13,0.19 \\
\quad 0.31,0.25,0)\end{array}$ & $\begin{array}{c}0,0.13,0.13,0.19, \\
0.31,0.25,0)\end{array}$ \\
\hline Finance $\left(c_{4}\right)$ & Lack of funds $\left(d_{41}\right)$ & 1 & $\begin{array}{c}(0,0.06,0.06,0.38 \\
0.31,0.19,0.06)\end{array}$ & $\begin{array}{c}0,0.06,0.06 \\
0.38,0.31 \\
0.19,0.06) \\
\end{array}$ & 1 & $\begin{array}{c}(0,0.13,0.25,0.13 \\
0.38,0.13,0)\end{array}$ & $\begin{array}{c}(0,0.13,0.25,0.13 \\
0.38,0.13,0)\end{array}$ \\
\hline $\begin{array}{l}\text { Project/ } \\
\text { technique }\left(c_{5}\right)\end{array}$ & $\begin{array}{l}\text { Engineering quality } \\
\text { problems }\left(d_{51}\right)\end{array}$ & 1 & $\begin{array}{c}(0.06,0,0.06,0.13 \\
0.5,0.19,0.06)\end{array}$ & $\begin{array}{c}(0.06,0,0.06 \\
0.13,0.5 \\
0.19,0.06)\end{array}$ & 1 & $\begin{array}{c}(0,0.06,0.06,0.19 \\
0.38,0.13,0.19)\end{array}$ & $\begin{array}{l}(0,0.06,0.06 \\
0.19,0.38,0.13 \\
0.19)\end{array}$ \\
\hline \multirow{5}{*}{$\begin{array}{l}\text { Organization/ } \\
\text { management } \\
\left(c_{6}\right)\end{array}$} & $\begin{array}{l}\text { Government's improper } \\
\text { administration }\left(d_{61}\right)\end{array}$ & 0.21 & $\begin{array}{c}(0.06,0,0.06,0.25 \\
0.38,0.19,0.06)\end{array}$ & \multirow{5}{*}{$\begin{array}{c}(0.03,0.07 \\
0.07,0.35,0.29 \\
0.17,0.03)\end{array}$} & 0.22 & $\begin{array}{c}(0.06,0,0.13,0.06, \\
0.38,0.38,0)\end{array}$ & \multirow{5}{*}{$\begin{array}{c}(0.01,0.08,0.11 \\
0.3,0.24,0.26,0)\end{array}$} \\
\hline & $\begin{array}{l}\text { Security hidden } \\
\text { danger }\left(d_{62}\right)\end{array}$ & 0.21 & $\begin{array}{c}(0.06,0,0.06,0.38, \\
0.31,0.13,0.06)\end{array}$ & & 0.22 & $\begin{array}{c}(0,0.06,0,0.38 \\
0.25,0.31,0)\end{array}$ & \\
\hline & $\begin{array}{l}\text { Lack of information on } \\
\text { key stakeholders' } \\
\text { interests }\left(d_{63}\right)\end{array}$ & 0.21 & $\begin{array}{l}(0,0.06,0.06,0.38 \\
0.19,0.31,0)\end{array}$ & & 0.18 & $\begin{array}{c}(0,0.19,0.13,0.31 \\
0.19,0.19,0)\end{array}$ & \\
\hline & $\begin{array}{c}\text { Decision-maker } \\
\text { moral }\left(d_{64}\right)\end{array}$ & 0.19 & $\begin{array}{c}(0,0.13,0.06,0.44 \\
0.25,0.13,0)\end{array}$ & & 0.19 & $\begin{array}{c}(0,0.13,0.13,0.38, \\
0.25,0.13,0)\end{array}$ & \\
\hline & $\begin{array}{l}\text { Decision-maker } \\
\text { competence }\left(d_{65}\right)\end{array}$ & 0.18 & $\begin{array}{c}(0,0.19,0.13,0.31, \\
0.31,0.06,0)\end{array}$ & & 0.19 & $\begin{array}{c}(0,0.06,0.19,0.38, \\
0.13,0.25,0)\end{array}$ & \\
\hline
\end{tabular}

Step 1. Weighted membership.

According to the weighting in Table 5, the weighted membership of $j$ th CSRF regarding ith CSRGs (probability or severity) was calculated using (13):

$$
M_{d_{i j}}=\left(m_{1 d_{i j}}, m_{2 d_{i j}}, \ldots, m_{7 d_{i j}}\right)=\omega_{i} \cdot \omega_{i j} \cdot\left(x_{1 d_{i j}}, x_{2 d_{i j}}, \ldots, x_{7 d_{i j}}\right) \text {, }
$$

where $\omega_{i}$ and $\omega_{i j}$ are the weighting functions of $i$ th CSRG and $j$ th CSRF of ith CSRG and $\left(x_{1 d_{i j}}, x_{2 d_{i j}}, \ldots, x_{7 d_{i j}}\right)$ is the membership of $d_{i j}$. As an example, the weighted membership assigned to the PO of $d_{i j}$ could be obtained:

$$
\begin{aligned}
M_{d_{11}} & =0.29 \cdot 0.22 \cdot(0,0,0.13,0.13,0.5,0.06,0.19), \\
& =(0,0,0.009,0.009,0.032,0.003,0.012) .
\end{aligned}
$$

Step 2. Defuzzification.

The defuzzification formula is the same as (11).

Step 3. IRL calculation and rank.

Results are shown in Table 9 and Figure 2.

In Table 9, rank of factors of the two models is listed. We can see that the risk rankings have slightly changed. The 
TABLE 7: Membership functions of the overall risk level.

\begin{tabular}{|c|c|c|c|c|c|c|c|c|}
\hline \multirow[b]{2}{*}{ Categories/groups } & \multicolumn{4}{|c|}{$\mathrm{PO}$} & \multicolumn{4}{|c|}{ MI } \\
\hline & $\begin{array}{l}\text { Group } \\
\text { weight }\end{array}$ & $\begin{array}{c}\text { Membership } \\
\text { function of CSRGs }\end{array}$ & $\begin{array}{l}\text { Membership } \\
\text { function of ORL }\end{array}$ & IRL & $\begin{array}{l}\text { Group } \\
\text { weight }\end{array}$ & $\begin{array}{c}\text { Membership } \\
\text { function of CSRGs }\end{array}$ & $\begin{array}{l}\text { Membership } \\
\text { function of ORL }\end{array}$ & IRL \\
\hline Policy/legal $\left(c_{1}\right)$ & 0.29 & $\begin{array}{c}(0.02,0.04,0.13,0.17 \\
0.36,0.16,0.1)\end{array}$ & & & 0.3 & $\begin{array}{c}(0.01,0.06,0.06 \\
0.19,0.35,0.19,0.14)\end{array}$ & & \\
\hline Society $\left(c_{2}\right)$ & 0.28 & $\begin{array}{c}(0,0.07,0.13,0.27 \\
0.25,0.19,0.08)\end{array}$ & & & 0.27 & $\begin{array}{c}(0,0.06,0.14,0.26 \\
0.37,0.17,0.01)\end{array}$ & & \\
\hline Environment $\left(c_{3}\right)$ & 0.06 & $\begin{array}{c}(0,0.06,0.06,0.13 \\
0.31,0.38,0.06)\end{array}$ & $(0.02,0.06,0.1,0.25$ & 467 & 0.06 & $\begin{array}{c}0,0.13,0.13,0.19 \\
0.31,0.25,0)\end{array}$ & $(0.01,0.07,0.11$ & 463 \\
\hline Finance $\left(c_{4}\right)$ & 0.06 & $\begin{array}{c}(0,0.06,0.06,0.38 \\
0.31,0.19,0.06)\end{array}$ & $0.32,0.19,0.07)$ & $4.6 /$ & 0.05 & $\begin{array}{c}(0,0.13,0.25,0.13 \\
0.38,0.13,0)\end{array}$ & $0.22,0.33,0.2,0.06)$ & 4.63 \\
\hline $\begin{array}{l}\text { Project/ } \\
\text { technique }\left(c_{5}\right)\end{array}$ & 0.06 & $\begin{array}{c}(0.06,0,0.06,0.13 \\
0.5,0.19,0.06)\end{array}$ & & & 0.06 & $\begin{array}{c}(0,0.06,0.06,0.19 \\
0.38,0.13,0.19)\end{array}$ & & \\
\hline $\begin{array}{l}\text { Organization/ } \\
\text { management }\left(c_{6}\right)\end{array}$ & 0.26 & $\begin{array}{c}(0.03,0.07,0.07,0.35 \\
0.29,0.17,0.03)\end{array}$ & & & 0.27 & $\begin{array}{c}(0.01,0.08,0.11,0.3, \\
0.24,0.26,0)\end{array}$ & & \\
\hline
\end{tabular}

TABLe 8: The PO, MI, and ORL of CSRGs and the project.

\begin{tabular}{|c|c|c|c|c|}
\hline Categories/groups & Value of PO & Value of MI & IRL value & Rank \\
\hline Policy/legal $\left(c_{1}\right)$ & 5.53 & 4.9 & 5.2 & 1 \\
\hline Project/technique $\left(c_{5}\right)$ & 4.8 & 5.07 & 4.93 & 2 \\
\hline Environment $\left(c_{3}\right)$ & 5.07 & 4.46 & 4.76 & 3 \\
\hline Society $\left(c_{2}\right)$ & 4.56 & 4.52 & 4.54 & 4 \\
\hline Finance $\left(c_{4}\right)$ & 4.93 & 4.13 & 4.51 & 5 \\
\hline Organization/management $\left(c_{6}\right)$ & 4.46 & 4.47 & 4.47 & 6 \\
\hline Overall risk & 4.67 & 4.63 & 4.65 & \\
\hline
\end{tabular}

TABLE 9: Rank comparison.

\begin{tabular}{|c|c|c|c|c|c|c|}
\hline \multirow{2}{*}{ Social risk factors } & \multicolumn{3}{|c|}{ Weighted average } & \multicolumn{3}{|c|}{ Date in Table 2} \\
\hline & $\mathrm{PO}$ & MI & IRL & Rank & Rank & Normalized values \\
\hline $\begin{array}{l}\text { Unfair compensation for housing demolition and } \\
\text { land requisition }\left(d_{11}\right)\end{array}$ & 0.325 & 0.388 & 0.355 & 1 & 1 & 1 \\
\hline Forced demolition $\left(d_{12}\right)$ & 0.301 & 0.368 & 0.333 & 2 & 3 & 0.89 \\
\hline Poor credibility of government $\left(d_{21}\right)$ & 0.31 & 0.301 & 0.305 & 3 & 2 & 0.90 \\
\hline Engineering quality problems $\left(d_{51}\right)$ & 0.292 & 0.304 & 0.298 & 4 & 4 & 0.85 \\
\hline Disturbance of local residents $\left(d_{22}\right)$ & 0.298 & 0.284 & 0.291 & 5 & 6 & 0.78 \\
\hline Environment pollution (water, land, noise, etc.) $\left(d_{31}\right)$ & 0.313 & 0.269 & 0.290 & 6 & 8 & 0.775 \\
\hline Violation of laws and rules $\left(d_{13}\right)$ & 0.277 & 0.301 & 0.289 & 7 & 5 & 0.79 \\
\hline Unreasonable relocation $\left(d_{14}\right)$ & 0.253 & 0.295 & 0.273 & 8 & 9 & 0.77 \\
\hline Government's improper administration $\left(d_{61}\right)$ & 0.24 & 0.297 & 0.267 & 9 & 7 & 0.78 \\
\hline Lack of funds $\left(d_{41}\right)$ & 0.301 & 0.218 & 0.256 & 10 & 12 & 0.67 \\
\hline $\begin{array}{l}\text { Negative attitudes of local residents towards } \\
\text { project }\left(d_{23}\right)\end{array}$ & 0.277 & 0.231 & 0.253 & 11 & 11 & 0.68 \\
\hline Security hidden danger $\left(d_{62}\right)$ & 0.201 & 0.289 & 0.241 & 12 & 10 & 0.72 \\
\hline $\begin{array}{l}\text { Lack of information on key stakeholders' } \\
\text { interests }\left(d_{63}\right)\end{array}$ & 0.237 & 0.215 & 0.226 & 13 & 13 & 0.60 \\
\hline Decision-maker moral $\left(d_{64}\right)$ & 0.218 & 0.218 & 0.218 & 14 & 15 & 0.52 \\
\hline Decision-maker competence $\left(d_{65}\right)$ & 0.203 & 0.225 & 0.214 & 15 & 18 & 0.50 \\
\hline Unemployment problem $\left(d_{25}\right)$ & 0.213 & 0.207 & 0.210 & 16 & 17 & 0.50 \\
\hline $\begin{array}{l}\text { Variations in policies or compensation } \\
\text { standards }\left(d_{15}\right)\end{array}$ & 0.204 & 0.215 & 0.209 & 17 & 14 & 0.54 \\
\hline Media dissemination $\left(d_{24}\right)$ & 0.15 & 0.218 & 0.181 & 18 & 16 & 0.50 \\
\hline
\end{tabular}

ranking of 8 factors has risen. They are forced demolition, disturbance of local residents, environment pollution, unreasonable relocation, lack of funds, decision-maker moral, decision-maker competence, and unemployment problems.
In part, it is because they have relatively larger weighting. Therefore, these factors should be paid more attention. The order of six factors decreased. The order of four factors is the same as before. 


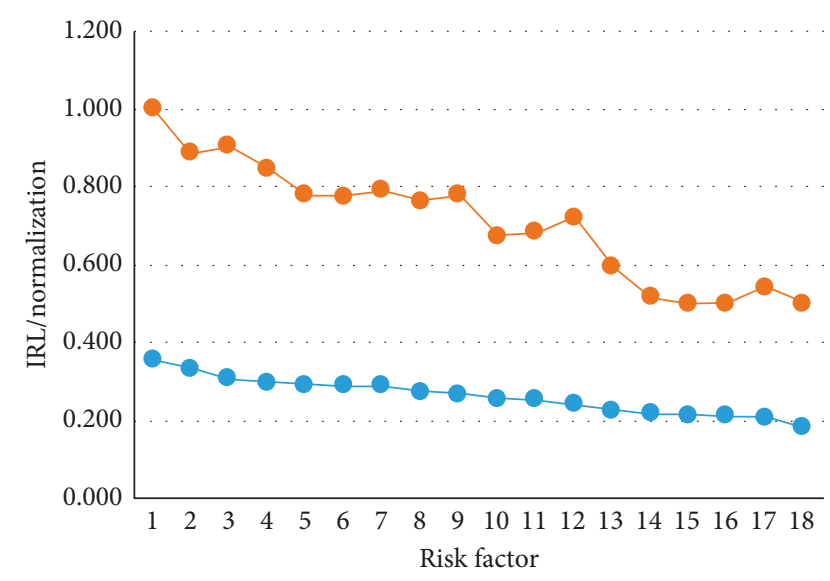

FIGURE 2: Risk factor rank comparison.

As is shown in Figure 2, of the top 10 factors, the top nine are the same, only the tenth is different. In a word, the social risk factors always keep the ranking in closeness no matter how the addition of fuzzy logic. It shows that the addition of fuzzy logic have slightly impacts on the results of the risk ranking.

\section{Social Risk Synthetic Management Framework in MCPs}

In this section, we proposed the strategies to mitigate the social risks from the perceptive of both risk management and stakeholder management. Social risk management framework is shown in Figure 3.

\subsection{Risk Factor Management}

6.1.1. Policy/Legal Risk. Unfair compensation for housing demolition and land requisition, forced demolition, violation of laws and rules, unreasonable relocation, and variations in policies or compensation standards are risk factors that need to be watched out due to higher mean value. These risk factors are all related to land expropriation and house demolition. Government, residents, contractor, and supervisor are the critical stakeholders. In response to these risk factors, first, the local government should work out a specific compensation and resettlement proposal to clarify principles for interest protection of affected villagers under the guidance of a series of laws and regulations. At the same time, the administrative department must be fair and impartial and avoid fraud for personal gain. Second, local cadres may indulge into residents' families for information gathering in order to understand the specific requirements, correct misunderstandings, and mitigate possible risks. Finally, to avoid violence, the superior departments also need to formulate policies to regulate the behavior of lower departments in order to prevent illegal incidents.

6.1.2. Society and Environment Risk. Poor credibility of government, disturbance of local residents, environment

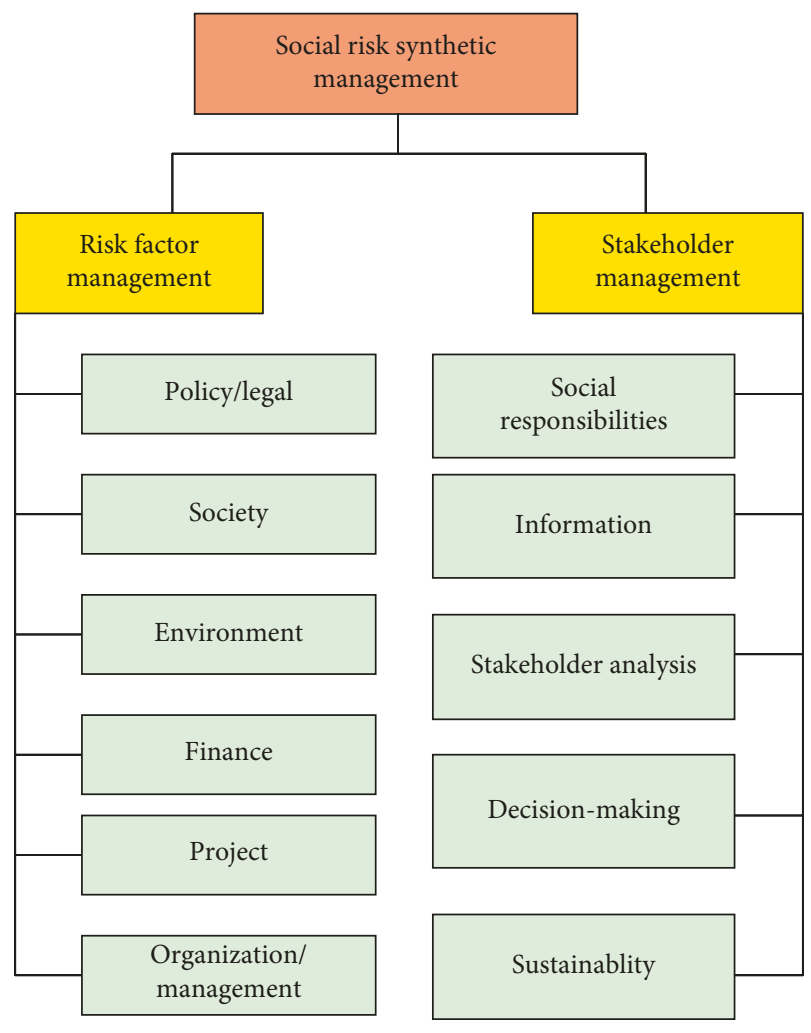

Figure 3: Social risk synthetic management framework.

pollution (water, land, noise, etc.), negative attitudes of local residents towards project, media dissemination, and unemployment problems are critical risk factors. First of all, to gain the trust, the government should publicize information regarding project (such as time frame, construction site, project usage, etc.), environmental impact assessment report, land requisition and house demolition compensation program, and resettlement plan by using various channels such as television, Internet, and notice boards in villages. On the other hand, from the previous analysis, we know that environmental pollution is an important factor leading to conflicts. Therefore, the construction party should take measures to protect the environment and minimize the impact on surrounding environment in accordance with the environmental protection policy. For example, the construction party can reasonably stack and dispose off construction wastes, purify the exhaust gas using the bag filter, and reduce noise pollution. Meanwhile, the supervisory authorities should also earnestly fulfill their responsibilities and obligations. Finally, to vulnerable group issues, governments and developers may organize re-employmenttraining programs to get new jobs.

6.1.3. Finance Risk. Lack of funds is also an important factor which may lead to social risks. The funding issues not only affect project quality and schedule, but also influence allocation of funds and compensation funds which can easily lead to discontent and conflict among residents. Therefore, to ensure adequate funds, the government should make 
detailed plans to allocate funds. Various investment modes such as public-private partnership, build-operate-transfer, and build-transfer can be adopted to attract large companies with sufficient funds to participate in projects.

6.1.4. Project/Technique. Engineering quality problems are related to people's lives and safety. The loss caused by engineering quality accidents is shocking. Quality accidents not only involve the interests of the main body of the construction market, but also affect the stability and development of the construction market. In response to this risk factor, the public sector should improve the engineering quality policy. For quality accidents caused by illegal acts, the responsible persons should be severely punished. Establishment of the scientific evaluation system and operation mechanism of government supervision, and the further standardization of government law enforcement can fundamentally guarantee the benefits of construction project quality.

6.1.5. Organization/Management. Government's improper administration, security hidden danger, lack of information on key stakeholders' interests, and decision-maker competence and moral deserve attention. Above all, the government should recognize its responsibilities and should not interfere too much the owners and contractors. Next, stakeholders should exchange information regularly to avoid the uncertainty caused by information asymmetry. Only by strengthening exchanges and cooperation among key stakeholders can the project proceed smoothly. At the same time, the trust relationship between the government and the local residents should be established to avoid contradictions. Thirdly, managing sectors should strengthen safety awareness and always put production safety in the first place in the life cycle of a project. At last, managers should not only strengthen the study of professional theoretical knowledge and improve their management ability, but also strengthen their social responsibility.

6.2. Stakeholder Management. According to Yang et al. $[33,34]$, successful stakeholder management can start from five aspects.

6.2.1. Social Responsibilities. Managing stakeholders with social responsibilities (economic, legal, environmental, and ethical) is the premise of stakeholder management and the most important for the success of stakeholder management [34-36]. According to Carroll [37], economic responsibility is the obligation to produce goods and services, sell them at reasonable prices, and gain benefits; legal responsibility is the obligation to obey laws and regulations; and ethical responsibility contains those aspects not included in laws but expected by society. Environmental issues involve air, dust, water, land and noise. The purpose is to protect the environment and to provide healthy living conditions [15]. In fact, no matter internal stakeholders or external stakeholders, if they all consider and solve problems from the perspective of social responsibility, any conflicts and contradictions will be solved smoothly. Therefore, the primary task of stakeholder management is to manage the social responsibility of stakeholders.

6.2.2. Information Gathering. This part mainly includes the identification of stakeholders and the exploration of their interests and needs. The effective method for identifying stakeholders includes personal past experience, snowball sampling, guidelines from governments or one's own organization, and professional services [33]. Personal past experience and snowball method are the most effective and commonly used. In Section 4, we determined the stakeholder related to social risk factors using the two methods. As for the exploration of their interests and needs, decision makers can communicate with key stakeholders through interviews and meeting methods.

6.2.3. Stakeholder Analysis. Decision makers need to comprehend the attributes and behavior of stakeholders, the impact on projects and conflicts and alliances between them. Communication and personal past experience is still important for gathering information about stakeholders. The other effective methods, such as focus groups, questionnaires, public engagement, and interviews, may also reveal preliminary issues that are of concern to a group or community.

6.2.4. Decision-Making. Resolving conflicts, developing suitable strategies, and predicting stakeholder responses are very important. If the conflicts among local governments, managing sectors, and the affected people cannot be effectively resolved, it will result in grave consequences. Even worse, community petitions and incidents originated by serious conflicts will affect social stability seriously. Therefore, decision makers not only need to formulate effective strategies, but also need to pay attention to the dynamic response of stakeholders. Meetings and workshops were regarded as the most common ways of implementing decisions. Negotiations can also be categorized as communication with stakeholders, especially when settling disputes and problems [33].

6.2.5. Sustainability. At last, in order to maintain the sustainability and effectiveness of stakeholder management, decision makers should also pay attention to the impact and changes of stakeholders, maintain communication with stakeholders properly and frequently, and keep a stable relationship.

\section{Conclusion}

In recent decades, with the rapid social development, major construction projects have become the driving force of social economic development, but at the same time, land acquisition, housing demolition, and environmental damage can affect and destroy living environment and interests of local farmers. The conflicts among local governments, managing sectors, and the affected people constantly occur. Therefore, it is 
urgent to carefully analyze social risks associated with MCPs, including the identification, estimation, and management of risk factors and related stakeholders, based on which social risks can be mitigated and controlled in a proper manner.

This paper identified 35 social risk factors and stakeholders of major construction projects in China by wideranging literature resources and case studies. After a questionnaire survey and calculation of the probability and impact for risk factors, 18 critical social risk factors were determined and were classified into six groups (CSRGs), that is, policy/legal, society, environment, finance, project/ technique, and organization/management. Then, a fuzzy synthetic analysis model was established to assess the overall social risks for MCPs. As a result, the overall risk level of MCPs in China is 4.65, which is between moderate and high. As for SCRGs, the policy/legal risk ranked first with an integrated risk rating of 5.2, which is high risk, followed by project/technique, environment, society, finance and, organization/management with the risk index 4.93, 4.76, 4.54, 4.51 , and 4.47 , respectively.

In terms of practical implications, these findings can assist managing sectors in managing and mitigating social risks in the life cycle of a construction project. First, the 35 social risks identified helps practitioners to better understand the underlying social risks, and the 18 critical social risks can be referred as a checklist for managers to identify risks and develop risk-response plans in MCPs. Second, the FSA model established in this study can be used to evaluate the overall risk level of MCPs, and this result can help policymakers understand risk levels in general. At last, the integrated framework model for risk management can help manage risks and reduce the negative impacts of social risks in MCPs.

\section{Appendix}

\section{A. Questionnaire}

We are conducting a questionnaire survey to assess social risks of major construction project for a water conservancy project. The data will be used purely for academic study. The identity of the respondents will not be disclosed. We invite you to spare few minutes of your precious time for such a questionnaire. Your participation will be of great help to us. Please finish it carefully according to your experience.

(1) Please tick $\sqrt{ }$ in any one rating that you think suitable for each item.

The questionnaire survey of magnitude of impact is similar.

(2) Is there any new additional risk factors which were not included in the questionnaire survey? Please estimate

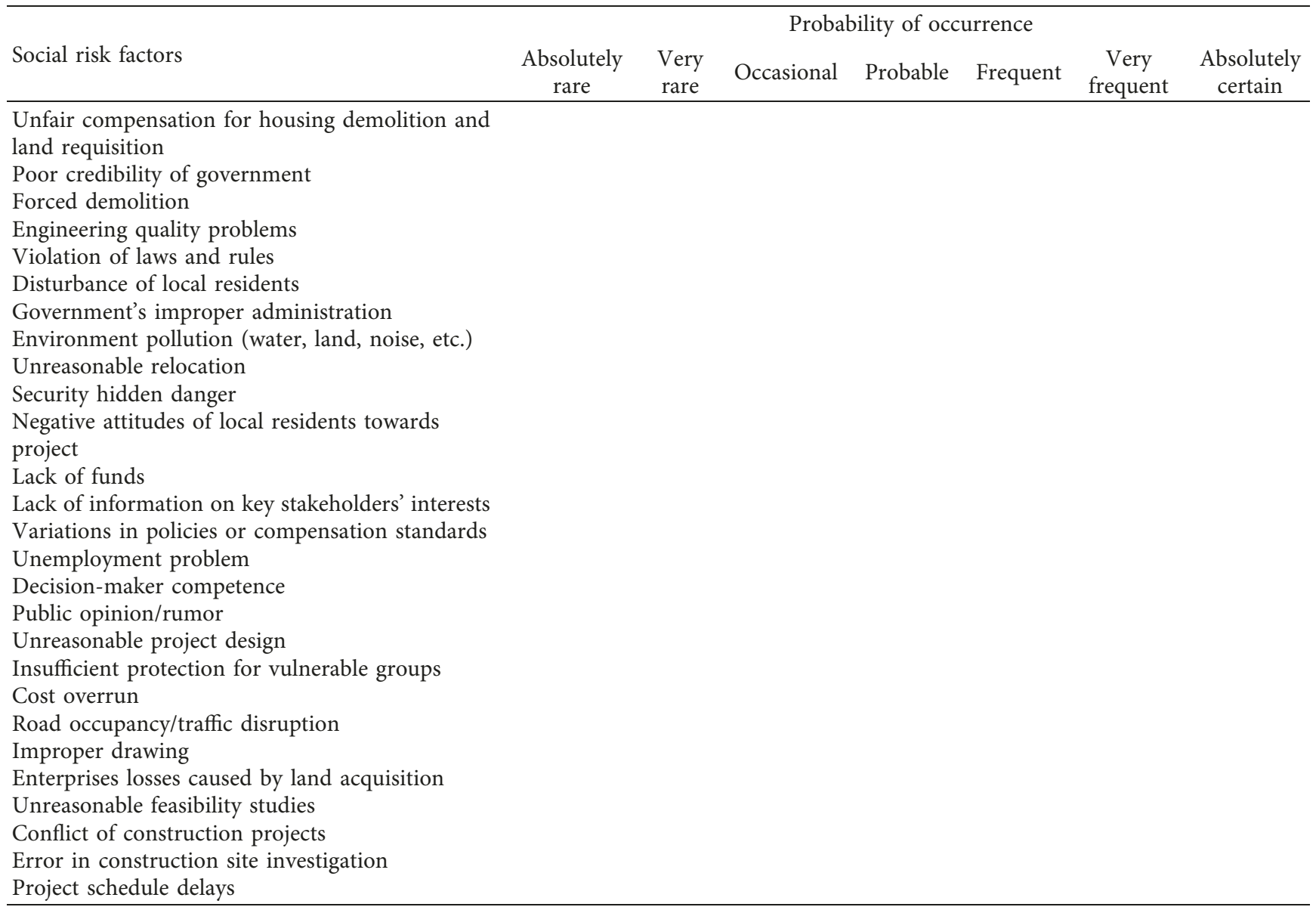


TABle : Continued.

\begin{tabular}{|c|c|c|c|c|c|c|c|}
\hline \multirow[b]{2}{*}{ Social risk factors } & \multicolumn{7}{|c|}{ Probability of occurrence } \\
\hline & $\begin{array}{c}\text { Absolutely } \\
\text { rare }\end{array}$ & $\begin{array}{l}\text { Very } \\
\text { rare }\end{array}$ & Occasional & Probable & Frequent & $\begin{array}{c}\text { Very } \\
\text { frequent }\end{array}$ & $\begin{array}{c}\text { Absolutely } \\
\text { certain }\end{array}$ \\
\hline $\begin{array}{l}\text { Lack of skill and experience of construction } \\
\text { workers } \\
\text { Cultural conflicts } \\
\text { Financial crisis } \\
\text { Rising consumer prices } \\
\text { Ineffective waste disposal } \\
\text { Uncertainties in weather and environment }\end{array}$ & & & & & & & \\
\hline
\end{tabular}

their probability of occurrence and magnitude of impact.

Thank you very much.

\section{B. Part of the Problems and Answers of Face-to- Face Interviews}

Question 1. What are you most worried about in the construction of the project?

Answer 1: Environmental pollution, such as the noise of machines and the dust of construction sites.

Answer 2: Quality of life, such as rising consumer prices and unemployment.
Question 2. What are you most dissatisfied with the local government's actions and practices?

Answer: Government leaders are not trustworthy, and they are not willing to listen to the public's opinions.

Question 3. Are you against this project? Why?

Answer 1: Yes. It had a negative impact on my life, such as the noise of machines and the dust of construction sites.

Answer 2: No. Because it can solve our water problem, and our living condition has more or less improved.

\section{The Questionnaire Results}

The questionnaire results

\begin{tabular}{|c|c|c|c|c|c|c|c|}
\hline \multirow[b]{3}{*}{ Social risk factors } & \multicolumn{5}{|c|}{ The questionnaire results } & \multirow[b]{3}{*}{$\begin{array}{c}\text { Very } \\
\text { frequent }\end{array}$} & \multirow[b]{3}{*}{$\begin{array}{l}\text { Absolutely } \\
\text { certain }\end{array}$} \\
\hline & \multicolumn{5}{|c|}{ Probability of occurrence } & & \\
\hline & $\begin{array}{l}\text { Absolutely } \\
\text { rare }\end{array}$ & $\begin{array}{l}\text { Very } \\
\text { rare }\end{array}$ & Occasional & Probable & Frequent & & \\
\hline $\begin{array}{l}\text { Unfair compensation for housing demolition and } \\
\text { land requisition }\end{array}$ & 0 & 0 & 2 & 2 & 8 & 1 & 3 \\
\hline Poor credibility of government & 0 & 1 & 2 & 1 & 5 & 4 & 3 \\
\hline Forced demolition & 0 & 1 & 4 & 1 & 5 & 2 & 3 \\
\hline Engineering quality problems & 1 & 0 & 1 & 2 & 8 & 3 & 1 \\
\hline Violation of laws and rules & 1 & 0 & 1 & 4 & 6 & 4 & 0 \\
\hline Disturbance of local residents & 0 & 1 & 1 & 6 & 2 & 4 & 2 \\
\hline Government's improper administration & 1 & 0 & 1 & 4 & 6 & 3 & 1 \\
\hline Environment pollution (water, land, noise, etc.) & 0 & 1 & 1 & 2 & 5 & 6 & 1 \\
\hline Unreasonable relocation & 0 & 1 & 3 & 2 & 5 & 4 & 1 \\
\hline Security hidden danger & 1 & 0 & 1 & 6 & 5 & 2 & 1 \\
\hline $\begin{array}{l}\text { Negative attitudes of local residents towards } \\
\text { project }\end{array}$ & 0 & 1 & 1 & 6 & 4 & 4 & 0 \\
\hline Lack of funds & 0 & 1 & 1 & 6 & 5 & 3 & 1 \\
\hline A lack of information on key stakeholders' interests & 0 & 1 & 1 & 6 & 3 & 5 & 0 \\
\hline Variations in policies or compensation standards & 1 & 1 & 2 & 5 & 4 & 2 & 1 \\
\hline Decision-maker moral & 0 & 2 & 1 & 7 & 4 & 2 & 0 \\
\hline Media dissemination & 0 & 2 & 2 & 6 & 4 & 2 & 0 \\
\hline Unemployment problem & 0 & 1 & 5 & 3 & 5 & 1 & 1 \\
\hline Decision-maker competence & 0 & 3 & 2 & 5 & 5 & 1 & 0 \\
\hline Public opinion/rumor & 0 & 2 & 3 & 5 & 5 & 1 & 0 \\
\hline Unreasonable project design & 1 & 2 & 3 & 4 & 3 & 3 & 0 \\
\hline Insufficient protection for vulnerable groups & 0 & 2 & 6 & 2 & 5 & 1 & 0 \\
\hline Cost overrun & 0 & 2 & 4 & 5 & 4 & 1 & 0 \\
\hline Road occupancy/traffic disruption & 1 & 1 & 2 & 7 & 3 & 2 & 0 \\
\hline Improper drawing & 1 & 3 & 2 & 6 & 1 & 3 & 0 \\
\hline Enterprises losses caused by land acquisition & 0 & 3 & 3 & 5 & 4 & 1 & 0 \\
\hline
\end{tabular}


TABle : Continued.

The questionnaire results

\begin{tabular}{|c|c|c|c|c|c|c|c|}
\hline \multicolumn{8}{|c|}{ The questionnaire results } \\
\hline \multirow[b]{2}{*}{ Social risk factors } & \multicolumn{7}{|c|}{ Probability of occurrence } \\
\hline & $\begin{array}{l}\text { Absolutely } \\
\text { rare }\end{array}$ & $\begin{array}{l}\text { Very } \\
\text { rare }\end{array}$ & Occasional & Probable & Frequent & $\begin{array}{l}\text { Very } \\
\text { frequent }\end{array}$ & $\begin{array}{c}\text { Absolutely } \\
\text { certain }\end{array}$ \\
\hline Unreasonable feasibility studies & 1 & 2 & 1 & 6 & 4 & 1 & 1 \\
\hline Conflict of construction projects & 0 & 4 & 3 & 4 & 4 & 1 & 0 \\
\hline Error in construction site investigation & 1 & 2 & 4 & 4 & 4 & 1 & 0 \\
\hline Project schedule delays & 0 & 2 & 5 & 6 & 1 & 2 & 0 \\
\hline $\begin{array}{l}\text { Lack of skill and experience of construction } \\
\text { workers }\end{array}$ & 1 & 2 & 6 & 3 & 1 & 3 & 0 \\
\hline Cultural conflicts & 0 & 5 & 3 & 6 & 0 & 1 & 1 \\
\hline Financial crisis & 3 & 4 & 4 & 3 & 2 & 0 & 0 \\
\hline Rising consumer prices & 0 & 3 & 8 & 2 & 2 & 1 & 0 \\
\hline Ineffective waste disposal & 2 & 0 & 4 & 10 & 0 & 0 & 0 \\
\hline Uncertainties in weather and environment & 0 & 8 & 5 & 1 & 1 & 1 & 0 \\
\hline
\end{tabular}

\section{Data Availability}

The data used to assess the social risks came from the questionnaire survey.

\section{Conflicts of Interest}

The authors declare no conflicts of interest.

\section{Acknowledgments}

This paper was supported by the National Natural Science Foundation of China (71573072 and 71603070).

\section{References}

[1] T. Wang, S. Wang, L. Zhang, Z. Huang, and Y. Li, “A major infrastructure risk-assessment framework: application to a cross-sea route project in China," International Journal of Project Management, vol. 34, no. 7, pp. 1403-1415, 2016.

[2] Z.-Z. Liu, Z.-W. Zhu, H.-J. Wang, and J. Huang, "Handling social risks in government-driven mega project: an empirical case study from West China," International Journal of Project Management, vol. 34, no. 2, pp. 202-218, 2016.

[3] J. Yuan, K. Chen, W. Li, C. Ji, Z. Wang, and M. J. Skibniewski, "Social network analysis for social risks of construction projects in high-density urban areas in China," Journal of Cleaner Production, vol. 198, pp. 940-961, 2018.

[4] T. Yu, G. Q. Shen, Q. Shi, X. Lai, C. Z. Li, and K. Xu, "Managing social risks at the housing demolition stage of urban redevelopment projects: a stakeholder-oriented study using social network analysis," International Journal of Project Management, vol. 35, no. 6, pp. 925-941, 2017.

[5] R. E. Kasperson, O. Renn, P. Slovic et al., "The social amplification of risk: a conceptual framework," Risk Analysis, vol. 8, no. 2, pp. 177-187, 1988.

[6] C. Samantra, S. Datta, and S. S. Mahapatra, "Fuzzy based risk assessment module for metropolitan construction project: an empirical study," Engineering Applications of Artificial Intelligence, vol. 65, pp. 449-464, 2017.

[7] Project Management Institute, A Guide to the Project Management Body of Knowledge (PMBOK ${ }^{\circledR}$ Guide), PMI, Newtown Square, PA, USA, fourth edition, 2013.
[8] T. Aven and O. Renn, "On risk defined as an event where the outcome is uncertain," Journal of Risk Research, vol. 12, no. 1, pp. 1-11, 2009.

[9] M. Abdel-Basset, M. Gunasekaran, M. Mohameda, and N. Chilamkurti, "A framework for risk assessment, management and evaluation: economic tool for quantifying risks in supply chain," Future Generation Computer Systems, vol. 90, pp. 489-502, 2019.

[10] R. F. A. Eskander, "Risk assessment influencing factors for Arabian construction projects using analytic hierarchy process," Alexandria Engineering Journal, vol. 57, no. 4, pp. 4207-4218, 2018.

[11] L. Zhang, M. J. Skibniewski, X. Wu, Y. Chen, and Q. Deng, “A probabilistic approach for safety risk analysis in metro construction," Safety Science, vol. 63, pp. 8-17, 2014.

[12] A. Qazi, J. Quigley, A. Dickson, and K. Kirytopoulos, “Project Complexity and Risk Management (ProCRiM): towards modelling project complexity driven risk paths in construction projects," International Journal of Project Management, vol. 34, no. 7, pp. 1183-1198, 2016.

[13] A. Nieto-Morote and F. Ruz-Vila, "A fuzzy approach to construction project risk assessment," International Journal of Project Management, vol. 29, no. 2, pp. 220-231, 2011.

[14] A. Bavafa, A. Mahdiyar, and A. K. Marsono, "Identifying and assessing the critical factors for effective implementation of safety programs in construction projects," Safety Science, vol. 106, pp. 47-56, 2018.

[15] O. Taylan, A. O. Bafail, R. M. S. Abdulaal, and M. R. Kabli, "Construction projects selection and risk assessment by fuzzy AHP and fuzzy TOPSIS methodologies," Applied Soft Computing, vol. 17, pp. 105-116, 2014.

[16] Y. C. Kou and S. T. Lu, "Using fuzzy multiple criteria decision making approach to enhance risk assessment for metropolitan construction projects," International Journal of Project Management, vol. 31, no. 4, pp. 602-614, 2013.

[17] Y. Xu, J. F. Y. Yeung, A. P. C. Chan, D. W. M. Chan, S. Q. Wang, and Y. Ke, "Developing a risk assessment model for PPP projects in China-a fuzzy synthetic evaluation approach," Automation in Construction, vol. 19, no. 7, pp. 929-943, 2010.

[18] R. K. Mavi and S. Craig, "Critical success factors of sustainable project management in construction: a fuzzy DEMATELANP approach," Journal of Cleaner Production, vol. 194, pp. 751-765, 2018. 
[19] X. Zhang, "Social risks for international players in the construction market: a China study," Habitat International, vol. 35, no. 3, pp. 514-519, 2011.

[20] Q. Shi, Y. Liu, J. Zuo, N. Pan, and G. Ma, “On the management of social risks of hydraulic infrastructure projects in China: a case study," International Journal of Project Management, vol. 33, no. 3, pp. 483-496, 2015.

[21] U. Beck, Risk Society: Towards a New Modernity, Sage, Thousand Oaks, CA, USA, 1992.

[22] P. C. Xiang and Y. P. Luo, "Researches on conduction mechanism of social stability risk in large-scale engineering projects," World Science and Technology Research and Development, vol. 36 , no. 4 , pp. 420-425, 2014, in Chinese.

[23] D. C. Huang, C. Z. Zhang, U. Lall, and M. Xu, "Study on the social stability risk of large hydraulic project," China Population, Resources and Environment, vol. 23, pp. 89-95, 2013, in Chinese.

[24] P. X. W. Zou, G. Zhang, and J. Wang, "Understanding the key risks in construction projects in China," International Journal of Project Management, vol. 25, no. 6, pp. 601-614, 2007.

[25] N. Xia, P. X. W. Zou, M. A. Griffin, X. Wang, and R. Zhong, "Towards integrating construction risk management and stakeholder management: a systematic literature review and future research agendas," International Journal of Project Management, vol. 36, no. 5, pp. 701-715, 2018.

[26] R. Holzmann and S. Jørgensen, "Social risk management: a new conceptual framework for social protection, and beyond," International Tax and Public Finance, vol. 8, no. 4, pp. 529-556, 2001.

[27] Z. He, D. Huang, C. Zhang, and J. Fang, "Toward a stakeholder perspective on social stability risk of large hydraulic engineering projects in China: a social network analysis," Sustainability, vol. 10, no. 4, p. 1223, 2018.

[28] J. Liu and Q. Wei, "Risk evaluation of electric vehicle charging infrastructure public-private partnership projects in China using fuzzy TOPSIS," Journal of Cleaner Production, vol. 189, pp. 211-222, 2018.

[29] A. P. C. Chan, P. T. I. Lam, Y. Wen, E. E. Ameyaw, S. Wang, and Y. Ke, "Cross-sectional analysis of critical risk factors for PPP water projects in China," Journal of Infrastructure Systems, vol. 21, no. 1, Article ID 04014031, 2014.

[30] K.-F. Chien, Z.-H. Wu, and S.-C. Huang, "Identifying and assessing critical risk factors for BIM projects: empirical study," Automation in Construction, vol. 45, pp. 1-15, 2014.

[31] Y. Wu, L. Li, R. Xu, K. Chen, Y. Hu, and X. Lin, "Risk assessment in straw-based power generation public-private partnership projects in China: a fuzzy synthetic evaluation analysis," Journal of Cleaner Production, vol. 161, pp. 977-990, 2017.

[32] E. E. Ameyaw and A. P. C. Chan, "Evaluation and ranking of risk factors in public-private partnership water supply projects in developing countries using fuzzy synthetic evaluation approach," Expert Systems with Applications, vol. 42, no. 12, pp. 5102-5116, 2015.

[33] J. Yang, G. Q. Shen, M. Ho, D. S. Drew, and X. Xue, "Stakeholder management in construction: an empirical study to address research gaps in previous studies," International Journal of Project Management, vol. 29, no. 7, pp. 900-910, 2011.

[34] J. Yang, G. Q. Shen, M. Ho, D. S. Drew, and A. P. C. Chan, "Exploring critical success factors for stakeholder management in construction projects," Journal of Civil Engineering and Management, vol. 15, no. 4, pp. 337-348, 2009.
[35] D. J. Wood and B. Gray, "Toward a comprehensive theory of collaboration," The Journal of Applied Behavioral Science, vol. 27, no. 2, pp. 139-162, 1991.

[36] A. B. Carroll, "The pyramid of corporate social responsibility: toward the moral management of organizational stakeholders," Business Horizons, vol. 34, no. 4, pp. 39-48, 1991.

[37] A. B. Carroll, "A three-dimensional conceptual model of corporate performance," Academy of Management Review, vol. 4, no. 4, pp. 497-505, 1979. 


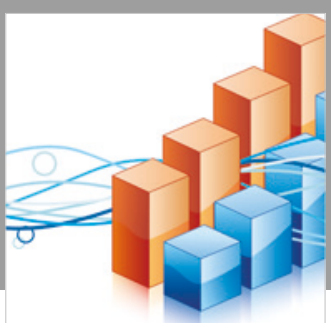

Advances in

Operations Research

\section{-n-m}
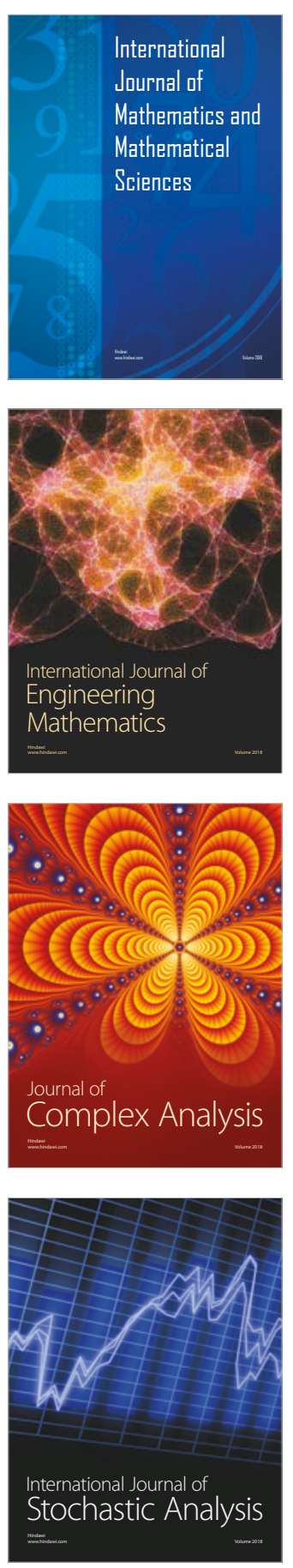
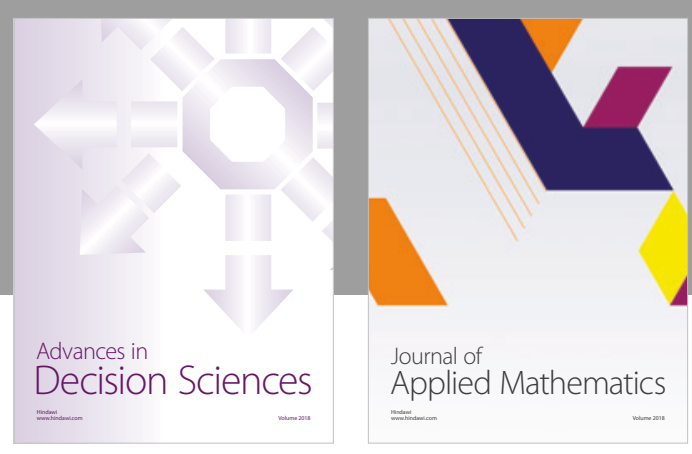

Journal of

Applied Mathematics
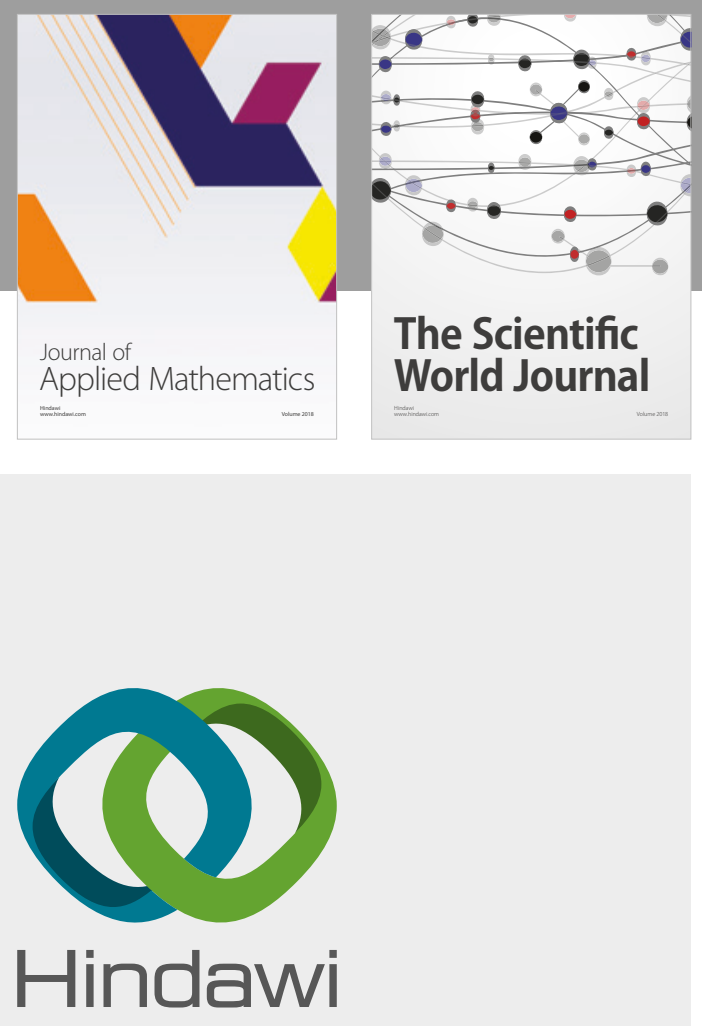

Submit your manuscripts at

www.hindawi.com

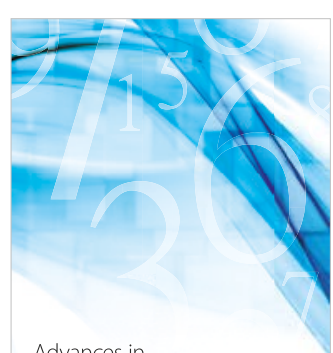

Advances in
Numerical Analysis
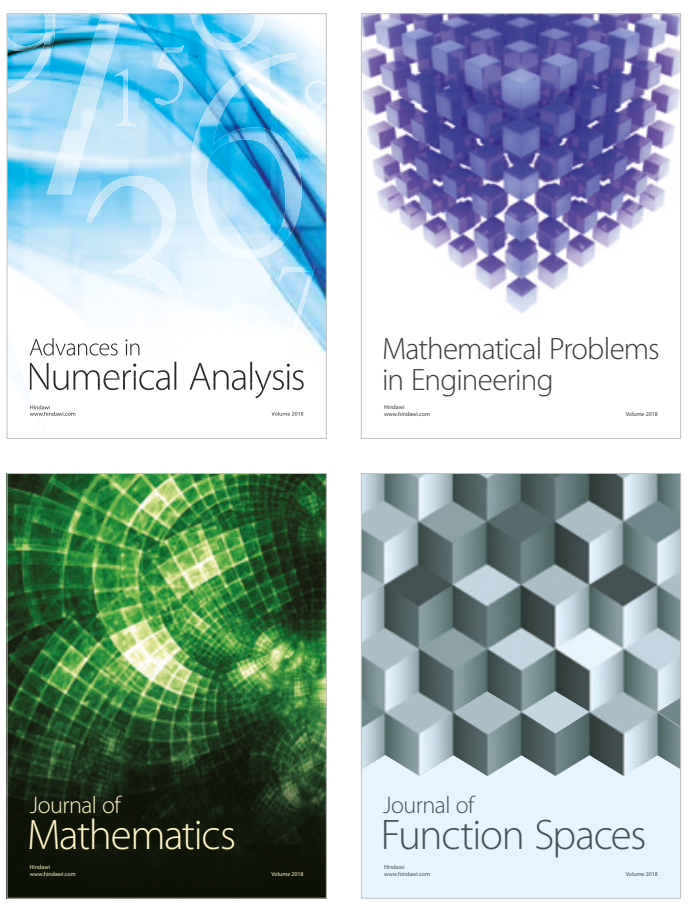

Mathematical Problems in Engineering

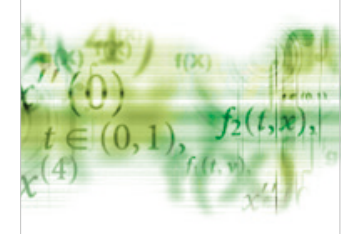

International Journal of

Differential Equations

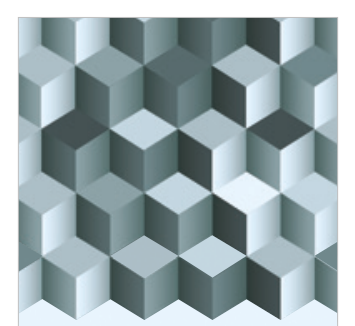

Journal of

Function Spaces
The Scientific

World Journal

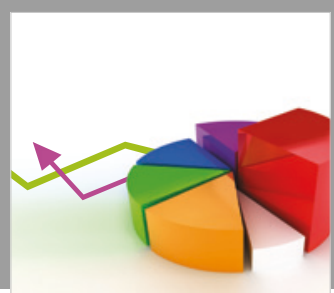

Journal of

Probability and Statistics
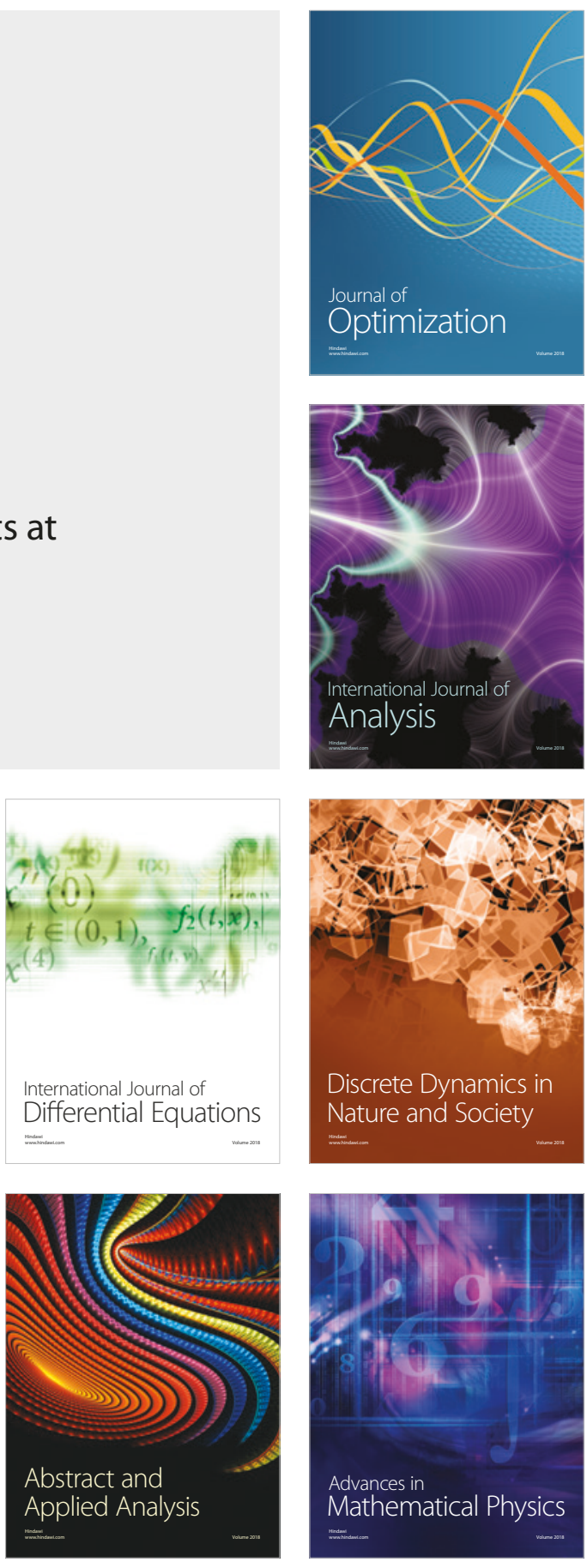